\title{
A HISTORY OF THE MEDICINAL USE OF TOBACCO $1492-1860^{*}$
}

by

\author{
GRACE G. STEWART
}

THE history of the medicinal use of tobacco before the Civil War has apparently not been documented in a single piece of writing. Yet, a review of publications on the subject shows that this plant was long used as orthodox medicine by the members of the medical profession. It seems to me to be a useful endeavour, therefore, to give the medico-historical account of tobacco, since: (1) Tobacco is an American plant, the Indians having presented it to the rest of the world; (2) According to Webster tobacco is America's most famous plant; (3) Tobacco is probably the only plant which was ever used as the panacea of panaceas; (4) Tobacco is now, and has been throughout history, an important product of the State of Maryland; (5) Tobacco was considered to have been one of the God-sent remedies; (6) Tobacco is a subject for controversy at present over the use of the cigarette for pleasure.

The hypothesis of medical men that there existed a panacea of panaceas prompted an age-long search for such a remedy. When Western European explorers of America discovered the tobacco plant, this hypothesis was one of the reasons that prompted the European medical men to seize upon the use of tobacco as medicine and subsequently to persuade themselves that tobacco was the long-sought panacea. Their later experiments with the plant as medicine confirmed the hypothesis of the physicians to their own satisfaction over a long period of years.

Very early, it was noted that tobacco had a habit-forming quality, and yet as the years passed the habit theory did not seem fully to explain the hold that tobacco medicine had upon its users. Eventually it came to be recognized that tobacco had an addictive property. The following account of Dr. Sigmund Freud's experience is related to show the reasoning of a distinguished doctor of medicine as he made the distinction between habit and addiction.

In 1894, Dr. Sigmund Freud at the age of thirty-eight suffered an irregular disturbance of his heart beat (arrhythmia) which Dr. Wilhelm Fleiss informed him was due to smoking-Dr. Freud was then smoking twenty cigars a day. Dr. Fleiss ordered Freud to stop smoking, and from time to time he reduced the number of cigars or stopped smoking them altogether, only to resume his full daily allowance of twenty.

When at the age of sixty-seven it was discovered that Freud had cancer, he wrote, '... smoking is accused as the etiology of this tissue rebellion.' Thirty-three operations were performed on Freud for cancer, his jaw was removed, and an artificial jaw was substituted and, at the age of eighty, he was still smoking an endless series of cigars.

Freud made an intensive study of his disease symptoms, as well as of his hypomanic mood following unsuccessful efforts to cease smoking. He admitted that the torture when not smoking was beyond his human power to bear.

* A paper submitted as a requirement in the Seminar in American Studies, Course 201, "Popular Science in America before the Civil War." Seminar conducted by Dr. Otho T. Beall. 


\section{A History of the Medicinal Use of Tobacco 1492-1860}

Dr. Ernest Jones, psychoanalyst, also studied Freud, and wrote of his smoking: 'That it might be called rather an addiction than a habit was shown by the extent to which he suffered when he was deprived of the opportunity to smoke'.1

To me, it seemed that the addiction hypothesis of the medical authority who studied Freud's use of the plant for pleasure would apply equally to the early, as well as the long-continued, use of tobacco as medicine. It is admitted at the outset, of course, that not all forms in which tobacco was used as medicine were in the addiction category.

This is a study of the medicinal use of the tobacco plant in America. For reasons which will be apparent as the record is developed much of the story of the use of the plant in Western Europe is included.

That tobacco is a native American plant has been proved by the factual evidence of botany, archaeology, anthropology, linguistics, and the records of antiquity. ${ }^{2}$

It is of interest in this history to know the origin of the word 'tobacco'. Among the Tainos, the pre-Columbian natives of the West Indies, their word tabaco was current. This was the word for the bifurcated tube used for inhaling cohobba (snuff). Historians of the period of the exploration of the Western Hemisphere were confused, however, and often wrote, in error, that tabaco was the name of the plant that was being used as medicine. The word, tabaco, as incorrectly applied to the tobacco plant, subsequently went through a variety of spellings. In the year 1598, John Florio in $A$ worlde of Wordes, an Italian-English dictionary published in London, said that the Italian word Nicosiana was rendered in English as 'the herbe Tobacco'. Following the publication of this dictionary, the variant spellings were continued for a time, but all variants were eventually dropped in favour of Florio's 'tobacco', and this word became the official common name of the tobacco plant. ${ }^{3}$

Tobacco is a genus (Nicotiana) of the nightshade family (Solanaceae), having viscid foliage and tubular flowers. There are more than fifty species of the genus, but only two species are considered here-tabacum and rustica. The chief physical differences between these two species lie in size, shape of leaves, and flower. Nicotiana tabacum was indigenous to South America, and Nicotiana rustica was indigenous to the West Indies and to North America east and immediately west of the Mississippi River and lower Eastern Canada. It is the nicotinic component which sets tobacco apart from all other plants. This, the active principle of tobacco, is a volatile, colourless, oily liquid, and a poisonous alkaloid.4 The nicotinic strength of the two species is believed to have been greater in their aboriginal states than it is in their cultivated states today. I have confined this discussion to the record of the medicinal uses of these two species as prescribed by the medical profession, although they were also used as folk medicine and by charlatans and quacks.

The written history of tobacco begins in the year 1492 when Christopher Columbus discovered American Indians treating their ills with leaves of a herb which he had never seen before. Between that date and 1536, European travellers to the New World

${ }^{1}$ The Consumers Union Report on Smoking and the Public Interest, ed. Ruth and Edward Brecher, Arthur Herzog, Walter Goodman, Gerald Walker and the Editors of Consumer Reports, Mount Vernon, N. Y., 1963, pp. 91-94.

2 Jerome E. Brooks, The Mighty Leaf, Boston, 1952, p. 10.

3 Sarah Augusta Dickson, Panacea or Precious Bane, New York, 1954, p. 42 n. 61.

4 Brooks, The Mighty Leaf, pp. 280-81. 


\section{Grace G. Stewart}

carried home a considerable body of medical knowledge concerning the plant, acquired from native American laymen, medicine men, and physicians in many parts of the Western Hemisphere. This knowledge was quickly spread by word of mouth and by books published and circulated throughout Western Europe. The result was that Western European physicians adopted tobacco as medicine. Then, in the year 1607 when the English began successfully to colonize the part of the Western Hemisphere which eventually became the United States, the physicians who came to the New World continued the use of tobacco as medicine as taught them in European universities, and they also added other uses as they discovered them in practice among the American Indians.

At this point, 1607, it might appear that the European story could be left behind, and the paper confined to what happened, first, in the American colonies and, later, in the United States. This could not be done, however, as will be seen from reasons which follow.

Before American medical schools were established, the colonies depended upon physicians born and educated in Europe and upon American-born physicians who secured their professional medical training in European universities. Even after American medical schools began to operate in the late eighteenth and early nineteenth centuries, many American physicians were educated in Europe because as students they had preferred to study there. Moreover, the immigration of physicians born and educated in Europe to the New World has continued from 1607 to the present day. There is another reason that European medicine has continued to influence New World medicine. Physicians of civilized nations do not live in a vacuum, for there is a constant exchange of medical knowledge among them. Hence, the European record of the medicinal use of tobacco is inextricably bound both with that of the American colonies and that of the United States, and the European-American record is necessarily treated as a unit in this paper. Naturally, I have omitted as much of the European account as I thought consistent with the paper's scope.

The date in United States popular science history at which the seminar, for which this paper was prepared, concluded its study was the year 1860 . Accordingly, the cut-off date for this paper is likewise the year 1860, although tobacco continued to be used therapeutically beyond that date.

Prior to its official naming and correct botanical classification, many different terms were used to designate the tobacco plant. Such of these terms as appear in this study are listed below:

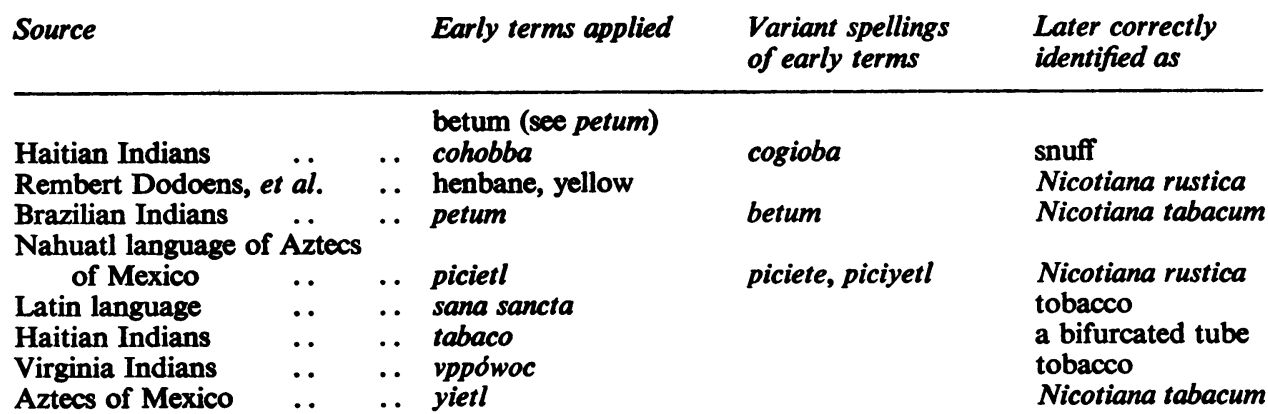




\section{A History of the Medicinal Use of Tobacco 1492-1860}

EARLY HISTORY, 1492-1536

Much has been written about the almost disease-free condition of the Indians when the Western Europeans began their invasion of the American continents in 1492. The implication is that, had the white men not come to the New World with their epidemic diseases, the Indians would have remained in their pristine state of good health. To prove their point, writers have cited examples of diseases not endemic to the Americas, which the Europeans carried to the Indians, such as measles, smallpox, mumps, typhus, etc. The absence of certain communicable or infectious diseases among the American Indians did not mean that they enjoyed a state of perfect health prior to the coming of the white man, however. In an indirect manner, early observers described the conditions from which the Indians were suffering at the time of the arrival of the white man when they told of the uses to which the Indians put one of the American herbs-that herb being the plant now identified as tobacco.

The first observer to note illness among the Indians was the discoverer of America himself. Christopher Columbus on his first voyage to America made an entry in his 'Journal', dated 15 October 1492, about dry leaves having medicinal value which a man in a canoe near the Island of Fernandina carried with him because they were esteemed for their healthfulness. ${ }^{5}$ It was also recorded in the life of Columbus published later by his son Ferdinand that the Indians on the Island of Veragua were always chewing a dry herb, which was sometimes mixed with powder and which, he believed, was the reason that the Indians' teeth were quite rotten and decayed. Columbus also wrote that on 5 November 1492, two of his crew reported that they had found many people on an island [Cuba] who always carried a burning torch with which to kindle fire and to perfume themselves with a certain herb. It was later learned that the form of the herb was the cigar and that it was then used as a disinfectant and to prevent fatigue. ${ }^{6}$

In the record of his second voyage to America in 1493, Columbus wrote that he had seen Indians placing a cane with two branches in their nostrils (the tabaco) and snuffing powder. In describing the narcotic effect of this sternutatory, Columbus said that the powder made the Indians lose consciousness. ${ }^{7}$

Friar Ramón Pané, a Catalan priest whom Columbus left in Hispaniola as a missionary to the Tainos Indians on his second voyage, wrote about a medicine man who was snuffing powder of an intoxicating plant. The powder caused the medicine man to be seized with rapture, following which experience he performed a ritual, drawing in the breath of a sick man, breathing on his forehead, temples and neck, and then announcing that he had drawn out the sickness from the veins of the patient. The friar identified the powdered herb as cogioba. He also observed that the Indians took cogioba to purge their nasal passages. For this purpose, they used a cane about one foot long, put one end in a nostril and the other in the powder, drew the powder through the nose, and were thoroughly purged. ${ }^{8}$

Amerigo Vespucci, Florentine navigator, wrote that on his second voyage to the New World in 1499, he saw Indians on the Island of Margarita off the coast of Venezuela chewing green leaves of an herb mixed with a pulverized substance [lime] to relieve thirst. ${ }^{9}$

Brooks, The Mighty Leaf, p. $11 . \quad$ 'Dickson, pp. 15, $27 . \quad$ ' Dickson, p. 26.

8 Dickson, pp. 23-24. Brooks, The Mighty Leaf, p. 15. 


\section{Grace G. Stewart}

Two later explorers, Alonso Niño and Cristobal Guerra, reported the same practice in 1500 in Venezuela with an additional use-as a dentifrice no less-to "whiten teeth'.10

A Portuguese explorer of Brazil, Pedro Alvarez Cabral, in the same year, reported the Brazilians using a medicinal herb, betum, which the Portuguese called fumo (smoke) and the 'holy herb' because of its powerful virtue in desperate cases-for ulcerated abscesses, fistulas, sores, inveterate polyps, and many other ailments. ${ }^{11}$

A book commonly called Cosmographice introductio, the product of collaboration, was printed in April 1507 by Vautrin Lud at St. Dié in the Vosges Mountains. This book in Latin which contained Vespucci's letters about his four voyages, including his observation on herb-chewing already mentioned, was accessible to educated readers all over Europe. ${ }^{12}$

In the year 1518, the Spaniard, Juan de Grijalva, saw Indians smoking in Yucatan, using a small cane lit at one end, which was later proved to have been a reed cigarette. No medicinal use for the cigarette was then reported, however, nor was one reported at any later date.

Fernando Ocaranza wrote in 1934 that in Mexico before the Conquest (1519), the Indians were using tobacco in these classes of medicines: anti-diarrhoeics, narcotics, and emollients. An application of tobacco leaves was used for pain; tobacco was used in powder form for relief of catarrhal conditions; and it was applied locally to heal wounds and burns. ${ }^{13}$

An Italian navigator, Giovanni da Verrazano, spent fifteen days on the shores of Narragansett Bay some time between 1523 and 1524. Of the Indians' therapeutic use of tobacco smoke, he wrote to his sponsor, Francis I of France: 'They [the Indians] live a long time and are rarely sick and if they are afflicted by a wound they heal themselves with fire'.14

Antonio de Herrera y Tordisillas, Spanish historiographer, writing from 1601 to 1615 of the Province of Tabasco in Mexico said of the medicinal use of tobacco in 1525: 'In this country, tabaco cures pain caused by cold; taken in smoke it is beneficial against colds, asthma and coughs; Indians and Negroes use it in powder in their mouths in order to fall asleep and feel no pain'. ${ }^{15}$

In the year 1529, Bernardino de Sahagún, Spanish missionary-priest, came to Mexico, and shortly thereafter began to gather material for a history of the country. He wrote that he derived the following information regarding medicinal use of piciete and yietl from four native physicians in Tlaltelulco:

For abscesses and sores on the head this remedy can be used: take a little lime mixed with a sufficient quantity of piciete ..... Against persistent head-aches, breathe in the odour of the green leaves of piciete.

For a cold or catarrh take the plant called piciete, either the green leaves or in powder, and rub them around the inside of the mouth with a finger, in order to expel the moisture.

Diseases of the glands of the neck are cured by opening the place with a small knife and, after cutting out the root, placing on it crushed piciete, mixed with the plant called yietl, all hot with salt, on the same spot. ${ }^{16}$

10 Dickson, p. 14, n. 24.11 Dickson, p. 63.12 Dickson, pp. 11-12.

13 Dickson, p. 60.

${ }^{16}$ As quoted in Dickson, p. $102 . \quad 16$ As quoted in Dickson, pp. 58-59. 


\section{A History of the Medicinal Use of Tobacco 1492-1860}

Gonzalo Fernández de Oviedo y Valdés published La Historia general delas Indias in 1535, and in it used the word tabaco correctly for the first time in print. Tabaco, said Oviedo, was the word used by the Haitian Indians for the instrument with which they inhaled the smoke of the herb. He further said that those who used the plant regarded it not only as healthy, but also as very holy-already some Spanish Christians were using it, especially those who were touched with the disease of syphilis. ${ }^{17}$

Jacques Cartier, Breton sea captain, wrote Brief recit, an account of his voyage, 1535-36, as far as modern Montreal in Canada, in which he described Indians smoking powder of a dried herb in a pipe to keep themselves healthy and warm. They sucked on their pipes so long that they filled their bodies full of smoke, and it came out of their mouths and nostrils as from a chimney. They never went anywhere without their pipes and herb. This was the first account to appear in print of the use of the medicinal pipe for smoking the herb. ${ }^{18}$

1537-1570

Between 1537 and 1559, fourteen books mentioning medicinal tobacco appeared in Europe and one in Mexico. These books were written by explorers, historians, missionaries, botanists and physicians. They were published in eight different languages: Dutch, English, French, Italian, Latin, Nahuatl, Portuguese, and Spanish, and their places of publication were: Antwerp, London, Mexico, Paris, Venice and Zamora. When not written by direct observers, the books repeated (not always accurately nor without embellishment) what the eyewitnesses had told of the various medicinal uses of tobacco from 1492 to 1536 in the Americas. The writers mentioned nineteen conditions and diseases as being treated by tobacco. One of the Jesuit authors proclaimed that the herb was God's remedy. (See Appendix No. 3, page 253.)

In addition to the books that were circulating, the use of tobacco spread to Europe. Some time before 1548, Luis de Goes, Portuguese Jesuit, took the plant and/or its seeds (Nicotiana tabacum) from Brazil to Portugal.19

In the year 1552, in the midst of the botanic Renaissance, herbal-pharmacopoeias began to include references to the herb as a curative agent. The earliest herbal to do so was a manuscript written in Tlaltelulco, Mexico. This manuscript reached Spain, England, and civilized Indians north of the Rio Grande. From this time onward, the simple was recommended less frequently, while compounds using tobacco with other ingredients became common. The Mexican herbal prescribed two compounds using picietl and piciyetl. The use of tobacco in an enema and in medicine to be taken by mouth and ingested seems to have been first suggested in this herbal. ${ }^{20} \mathrm{~A}$ sampling of formulae using tobacco medicinally from 1529 to 1858 is given on pages 256-58, Appendix No. 4.

The first delineation of the tobacco plant (Nicotiana rustica) appeared in a herbal published by Rembert Dodoens, physician-botanist, at Antwerp in 1553, for which the artist who prepared the plates for the book obviously had a growing plant available. Dodoens' caption for the woodcut of the plant was Hyoscyamus luteus (yellow

${ }^{17}$ F. W. Fairholt, Tobacco: Its History and Associations, London, 1859, pp. 204-5.

18 Brooks, The Mighty Leaf, pp. 18-19.

10 Dickson, pp. 78-79. 


\section{Grace G. Stewart}

henbane, a member of the nightshade family). In classifying tobacco as a member of the nightshade family, Dodoens was correct, but the plant was not henbane. ${ }^{21}$

In 1555, Richard Eden translated into English what Friar Pané had observed in 1493 at Hispaniola as published in 1511 at Seville by Peter Martyr. This translation provided the first opportunity to the English-speaking people to read in their own language from a printed book about the medicine called an intoxicating plant. 22

André Thevet, Franciscan monk, returned to France from Brazil in February 1556. The following year, Thevet published in Paris a book commonly called France Antarctique. In this book, Thevet warned that petum caused weakness, even fainting. One of the woodcuts illustrating Thevet's work showed a medicine man with an attendant blowing smoke on a patient from a primitive cigar. ${ }^{23}$ In a study published in 1958 , the authors say that the woodcut represented a man being cured of yaws. ${ }^{24}$ This is the first case reported of medicinal smoke being blown on a patient. Because, as the years passed, tobacco was applied in so many different ways to practically every part of the human body, a descriptive catalogue has been included in Appendix No. 5, page 258.

The year 1560 is important in tobacco history because that is the year that the French ambassador to Portugal, Jean Nicot, from whom tobacco was to get its genus name, began to experiment with the medicinal herb and to spread the word of his successful results. Although not a doctor of medicine, Nicot's experiments were performed with precision, and he kept meticulous case histories, of which the following report by a third person is an example:

He [Nicot] was informed one day by one of his pages that a young man, who was a relative of his, had made trial of this herb, mashed with the pulp and juice together, on a sore which he had on his cheek near the nose, caused by a cancerous growth, which was already attached to the cartilages, and he was wonderfully better from it. Because of this $M$. Nicot had the sick boy brought to him and had the application of the herb continued for eight or ten days and the growth was completely healed.

While cures were being effected, Nicot sent his patients to the physician of the King of Portugal for certification. Since Nicot was the first to tell others in France of the remedial virtues of the herb, the plant was being called Nicotiane in honour of him as early as 1565 , and perhaps earlier. Conrad Gesner, botanist, physician and scientist at Zurich, referred to the plant as Nicotiane in French and as Nicotiana in Latin. Gesner conducted experiments with a leaf of tobacco and in 1565 described the narcotizing power and the poisonous quality that he found in the herb (see Appendix No. 6, page 260). It is believed that, had Gesner not died within a short time after performing his experiments, he would have succeeded in isolating nicotine, ${ }^{25}$ and thus would have saved countless thousands from the poisonous effects of nicotian therapy.

Between 1560 and 1570, in addition to five histories mentioning medicinal tobacco, other books important to the development of tobacco therapeutics came out. Pietro Andrea Mattioli published a materia medica at Venice in 1565 , in which he included

1 Dickson, pp. 33-34. 22 Dickson, pp. 24-25. 23 Dickson, p. 37.

« H. Silvette, P. S. Larson, and H. B. Haag, 'Medical Uses of Tobacco, Past and Present' p. 12. (Reprint from Virginia Medical Monthly, September 1958, 85).

${ }^{26}$ Dickson, p. 68. 


\section{A History of the Medicinal Use of Tobacco 1492-1860}

a description of henbane. ${ }^{26}$ In Paris, in 1567, Estienne and Liébault produced a work on horticulture, commonly known as Maison rustique, in which they printed a chapter on Nicotiane, saying that it held first place among medicinal plants because of its singular and almost divine virtues. ${ }^{27}$ This chapter was based on information obtained from Nicot.

In 1568, Thomas Hacket translated into English Thevet's France Antarctique which he titled The new found worlde, thus making it possible for the English-speaking people to read in their own language Thevet's list of cures and to see the illustration of the Brazilian Indian's treatment with medicinal smoke. By the year 1570, and possibly earlier, tobacco had reached England in plant form..$^{28}$

The writers of the decade, 1560-1570, mentioned twenty-two diseases and other conditions then being treated by the herb. They told how the plant was being handled and they gave new forms for its application. In Maison rustique alone there were eight formulae requiring the plant as an ingredient which was pounded, distilled, mashed, and made into ointment and poultices. In distilling the plant, the experimenters were extracting what we now know as nicotine. How the plant was handled, physically, from 1492 to 1840, appears in Appendix No. 7, page 260, and tobacco elements, compounds, and by-products as well as instruments used to administer tobacco medication, 1492-1830, are catalogued in Appendix No. 8, page 260.

$1570-1585$

Between 1570 and 1585 the panacea-of-panaceas doctrine and practices were elaborated, assembled, and firmly established. In this fifteen-year span, forty-five books mentioning the new treatment were published, distributed thus:

22 herbal-pharmacopoeias

14 histories

2 dictionaries

5 horticulture books

2 medical books

Seven of the twenty-two herbals were translations into the English language. Among the twenty-two, there were five which were written both in Latin and in the vernacular of the Western European authors, and seventeen of them were translated from one living European language to another as well as into Latin.

One of the herbals was written by two French collaborators, L'Obel and Pena, whose book called Adversaria was published in 1570-71 in London, illustrating Nicotiana tabacum and explaining that the plant was doubtful henbane, with the leaves of solanum (nightshade family). ${ }^{29}$ These men also noted a narcotic effect of the herb-that it lulled brains.

The bubonic plague was epidemic almost every year of the sixteenth century in some part of Europe. There were a number of serious outbreaks in Great Britain, but the plague could be managed by the use of Nicotiane, said Dr. Antoine Sarrasin in his book, De peste commentarius, published at Geneva and at Lyons in 1572.30

26 Dickson, pp. 38-39. $\quad{ }^{27}$ Dickson, pp. 72-75. $\quad 20$ Dickson, p. 119.

29 Dickson, pp. 37-39. 30 Dickson, p. 100. 


\section{Grace G. Stewart}

In 1573, in contributing to the panacea-of-panaceas doctrine in England, William Harrison first wrote, 'The herb is a sovereign healer', and then with the turn of his pen said ' . . . yet is not the smoke or vapour thereof [tabaco] so profitable to be receaved inwardly'.81 And in 1574, Dr. Dodoens in a new Latin herbal, speaking of henbane, said ' . . . it should only be prescribed for warm and robust constitutions. The use of this kind of henbane or its leaves is not safe for weak or old people . . . it is better to mix the leaves of this with others in order to temper its coldness.' ${ }^{32}$ (See Appendix No. 9, page 261.)

An English translation of the works of Nicolás Monardes, physician of Seville, came out in 1577. Monardes had written about the plants of the West Indies and he had actually used tobacco in medicine. He had included in his writings a lengthy section on sana sancta, praising it for curing many ailments besides those mentioned in the chapter on Nicotiane written by Estienne and Liébault. John Frampton, the English translator of Monardes' works, called his translation Ioyfull Newes out of the new founde world. This became the textbook for English physicians who promptly accepted tabaco as the greatest panacea ever known to man. ${ }^{33}$ (See Appendix No. 10, page 262.) The part of Monardes in preparing the contents of the cornerstone for the panacea-of-panaceas structure was the cataloguing of about sixty-five diseases and other conditions which sana sancta would cure, in addition to those already assembled by other writers. He also recommended a few formulae and suggested new ways of mangling the plant to obtain its essence.

After 1577 , when a physician saw a patient, it was more likely than not that the invalid would demand and/or that the physician would prescribe tabaco in the form of a decoction, an ointment, a powder, or a syrup. The patient might suffer from fits, gangrene, gout, halitosis, intestinal worms, madness, or tooth decay-the remedy was the same. If the patient needed a purge upwards or downwards-the emetic was tabaco. Monardes gave sixteen narcotic uses for tabaco-for treating every conceivable kind of ache, pain, or soreness. He admitted, though, that tabaco could cause people to be out of their mind.

In 1578 Dodoens' Dutch herbal was twice translated into English, still calling the plant yellow henbane, and this herbal, together with the 1577 English version of Monardes, became the English-speaking physicians' constant guides in prescribing the panacea of panaceas."

Diego Durán, Dominican priest, historian of Mexico, wrote in 1581 that the holy herb deadened flesh 'so as to feel no pain'. To accomplish the numbness, he advised, 'Put in much picielt mixed with various insects and make an ointment'. ${ }^{35}$

When a manuscript was written about 1585 by the Portuguese Jesuit, Fernão Cardim, containing passages on the Indian women of Brazil 'drinking' the holy herb for medicinal purposes, the use of the herb was firmly established. ${ }^{\mathbf{3 6}}$

If the physicians of the time had not been so obsessed with what they considered to be the virtues of the panacea, they would have paid more attention to the four authorities between 1570 and 1585 who warned of harmful effects of the herb.

31 As quoted in Fairholt, p. 45. 2s Dickson, pp. 36-37.

23 Jerome Edmund Brooks, Descriptive Notes Adapted from Books, Manuscripts and Drawings Relating to Tobacco from the collection of George Arents, Jr., Washington, 1938, pp. 24-25, 27.

"Dickson, p. 46. "As quoted in Dickson, p. 144. "Dickson, pp. 66-67. 


\section{A History of the Medicinal Use of Tobacco 1492-1860}

1586-1600

The physicians who finished the panacea structure between 1586 and 1600 had a great deal of aid from others, such as botanists, poets, historians, et al. This period started with a pronouncement by Jacques d'Alechamps, botanist at Lyons, that Nicotiana was a panacea for all sorts of ailments. The total number of books written about tobacco medicine was still high, for thirty-eight were published, all told. Three of them dealt entirely with tobacco, two were materia medicas, eleven were herbalpharmacopoeias, etc. Sixteen of the books were in the English language, and these included three long poems on the medicinal uses of tobacco. Out of the total of 254 diseases and other conditions reported as being treated by tobacco between 1492 and 1860, seventy-one were reported between 1586 and 1600. In these fifteen years, physicians invented new formulae using tobacco, and they found new end uses for the plant, for they put it in patients' eyes and ears, as well as in or on other parts of the body in ways previously described. Twenty-one volumes referring to tobacco were written on the continent of Europe during this period, but no comment will be made on that contribution here.

In 1586, English colonists returned to England from their unsuccessful attempt to settle Virginia, and the repatriates planted their seeds of Nicotiana rustica, indigenous to Virginia, at Gloucestershire, England. These colonists had personally seen the Indians of Virginia using vppówoc, medicinally. In 1588, Thomas Hariot published his work on the first Roanoke colony, entitled $A$ Briefe and true report of the new found land of Virginia. In this narrative, the account of the Virginia Indians' medicinal use of vppowoc was the same as that already recorded for Indians in other parts of the Americas. ${ }^{37}$

A Latin edition of Mattioli's Materia medica, edited by Joachim Camerarius, was published in Germany in 1586 which illustrated Nicotiana tabacum, the best and most scientific representation of the plant in any sixteenth-century text. This species was indigenous to South America. ${ }^{38}$

The best English surgeon of the day, William Clowes, published in 1588, A prooued practise for all young chirurgians, concerning burnings with Gunpowder, and woundes made with Gunshot, Sword, Habbard, Pyke, Launce, or such other. This book was primarily intended for young surgeons who would be attending the armed forces, and it was liberally provided with case histories. Dr. Clowes included in the proved practise an account of the use of tobacco in unguents, one of them his own invention. ${ }^{39}$ The next year another English surgeon, John Banester, wrote An Antidotarie Chyrurgical in which he recommended tobacco balmes, gargarismes (gargles), and waters. ${ }^{40}$

In Mexico, Juan de Cárdenas, physician, published a book in 1591 treating tobacco in extenso, which was sent to London. Dr. Cárdenas was perhaps the most important contributor to the panacea doctrine, for he said, 'To seek to tell the virtues and greatness of this holy herb, the ailments which can be cured by it, and have been,

${ }^{87}$ Brooks, The Mighty Leaf, p. 49.

${ }^{38}$ Brooks, Descriptive Notes, p. 2.

s9 Dickson, pp. 174-76.

¿ Samuel Evans Massengill, A Sketch of Medicine and Pharmacy, Bristol, Tenn., 1943, p. 301. 


\section{Grace G. Stewart}

the evils from which it has saved thousands, would be to go on to infinity.' ${ }^{\mathbf{4} 1}$ What more could one want?

The first English book entirely on the subject of Tabaco (its title), was published in 1595 by Anthony Chute. This tract consisted of a résumé of tobacco information from Liébault, Monardes, and others, and Chute, with this publication, practically roofed the new panacea-of-panaceas structure single-handed. He wrote, 'Anything that harms a man inwardly from his girdle upward might be removed by a moderate use of the herb.'42

Another Englishman, Hugh Plat, published a book in London in 1596 on remedies, which repeated the list of the Indians' medicinal uses of the 'hearbe Tabaco'. John Gerard's English herbal, based on that of Dodoens, came out in $1597 .^{43}$

At long last, after more than a century of medicinal use, the 'herbe' was to get its English name when, in 1598, Florio published his Italian-English dictionary in London-A worlde of Wordes. Here he rendered the Italian Nicosiana in English as 'the herbe Tobacco', and his rendering has stuck as the official common name of the herb. ${ }^{44}$

In the same year, the greatest botanist of the time, Caspar Bauhin in Germany, made an important contribution to the botany and nomenclature of tobacco when he gave a correct scientific grouping to various kinds of the plant. He described four kinds, two of which were the species discussed in this paper. The first, the ordinary large tobacco, which he called Nicotiana maior latifolia, is the species known now as Nicotiana tabacum, and the other he called Nicotiana minor (formerly called yellow or doubtful henbane) which was later to be named Nicotiana rustica. The name, Nicotiana, officially assigned for the genus, thus immortalized the name of Nicot. ${ }^{45}$ This Latinized form of the French Nicotiane had been used as early as 1565, but the plant had not then been classified botanically. Between 1598 and 1600 four more English books on the subject of medicinal tobacco were published. However, the panacea structure of the sixteenth century had its critics. Some typical end-of-thecentury criticisms and doubts follow:

Harrison:'How doo men extoll the use of Tabacco in my time, whereas in truth ... it is not found of so great efficacie as they write.'

Clowes: Found not that effect in the herb that he looked for.

Cárdenas and Chute: The patient should be careful about the conditions under which the herb was used.

Gerard: 'If taken after meals the herb would infect the brain and liver.'

Vaughan: Tobacco should be avoided by (among others) women with child and husbands who desired to have children."10

On this note, the sixteenth century closed.

4 Dickson, pp. 94-96.

12 Charles F. Mullett, 'Tobacco as a Drug in Earlier English Medicine', Ann. Med. Hist., Third Series, II, No. 2, 1940, p. 110.

4 Dickson, p. 98.

4 Dickson, p. 42.

4 Dickson, pp. 55, 68.

16 Mullett, p. 116. 


\section{A History of the Medicinal Use of Tobacco 1492-1860}

$1601-1700$

Tobacco was at the height of its fame as a sanatory herb when the seventeenth century dawned. The promotional work of the writers had been completed, and since there seemed to be little to add to the catalogue of diseases and other conditions treatable by tobacco, it would appear that the publication of books on therapeutic tobacco could have ceased. This was not the way it worked, however. The first book published about medicinal tobacco in London in the seventeenth century came out in 1602 under a pseudonym, Philaretes. Since Philaretes was exposing the harmful effects of tobacco in Work for chimny-sweepers, he probably found it expedient to write anonymously. He declared that no one remedy could be applied to all maladies any more than one shoe could well serve all men's feet; tobacco purged its users too violently, and it dried up the sperm of a man so that if used over-long the propagation and continuation of mankind must needs be abridged. Tobacco had a stupefying effect, not unlike opium; it increased melancholy greatly and wasted the liquid part of the blood, and more. ${ }^{47}$ This book brought forth three in defence of tobacco, all published in London in 1602, and thus the stage was set for the London tobacco controversy that continued for about sixty-five years. Due to the controversy, indefatigable researchers added to the list of diseases that tobacco would cure, while those opposed to the use of tobacco medicine added to the list of its harmful effects. Pamphleteers were hired to write on the subject, and before the heat of the controversy was over in 1665, twenty-six books on the medical phase of the question had been published in London alone (see Appendix No. 11, page 263). Eight of the physician-writers were proponents, three were opponents, and two others could see both harm and good in the medicine. Other writers, not physicians, who took part in the paper war on tobacco medicine included the King of England, a Welsh judge, and poets. (The controversy was carried on on the continent of Europe also, but no comment will be made on that part of the controversy here, other than to say that the debate on the continent was not so extensive as that in London.)

The books published in the London controversy listed 149 diseases and other conditions which could be treated with tobacco, some of which had been mentioned before the seventeenth century and some of which were new. Among those writing against the medicinal and the social uses of tobacco was King James I of England. His book, A Counterblaste to tobacco, in 1604, was responsible for a large part of the controversy which followed. The king denied that tobacco had any medical value. He said that autopsies performed on some notorious smokers revealed that their inward parts were soiled and infected with an oily kind of soot. He further wrote: '... tobacco was first found out by some of the barbarous Indians to be a preservative or antidote against the pox, a filthy disease whereunto these barbarous peoples are very much subject, so from them was brought this use of tobacco as a stinking and unsavoury antidote for so corrupted and execrable a malady, the stinking suf-fummigation whereof they yet use against that disease ...' He hoped that no English gentleman would willingly risk the insinuation that he was afflicted with the malady by indulging in the same remedy. ${ }^{48}$

Dr. Edmund Gardiner, in 1610, conceded that some poison existed in tobacco

"7 Mullett, p. 112.

48 Albert G. Nicholls, 'Herba Panacea', Canad. Med. Assoc. J., 1942, 36, p. 279. 
and that tobacco relieved rather than cured, and yet among his recipes depending upon the herb, he contradicted himself by prescribing it for tetanus, the first physician to do so. Among those who made sweeping denunciations, one said, 'No plant except hemp was so pernicious to man's life as tobacco'. Another jeered at the notion of tobacco as the only sovereign experimental cure. And still another asked, 'Is not now this high placed remedy discovered to be a monster of many diseases?' The older criticism of its use because of its narcotic property was repeated during the debate in order to condemn the medicinal use of tobacco.

All of this writing was truly shaking the foundation of the panacea structure, but it survived a little longer as some therapeutists continued to make inordinate claims, saying that tobacco cured almost all diseases, that if all the ailments were set down that tobacco would cure, it would require a big volume; that all ages, all sexes, all constitutions, young and old, men and women, the sanguine, the cholerick, the melancholy, and the phlegmatic could take tobacco without any manifest inconvenience.

One of the most revolting of the formulae using tobacco was published by two physicians late in the controversy. This compound called for hiding the tobacco leaves in horse dung to ferment, for adding oil of brimstone and other ingredients, and for administering the medicine by mouth, by the spoonful.

Some extravagant suggestions coming out of the controversy were that the roots, seeds, and stalk should be used therapeutically. The by-products, tobacco and tobaccopipe ashes, were prescribed, too. New compounds were recommended using the medicine in the form of enema, gruel, pills, plasters, chewed-tobacco poultices, snuff salve, tea, and wine.

A part of the rebuttal to the physicians who contended that tobacco should be used only as medicine and only upon professional advice was that patients were successfully treating themselves and that, therefore, the physicians were losing business. It was claimed that it was not honourable to use, for pleasure, a product that should be reserved for medicinal uses. ${ }^{49}$

The first English book on first aid came out in 1633 recommending tobacco as an antidote to poison and as an unguent for wounds or bruises, etc. 50

The seventeenth-century European dispute over tobacco had a number of facets other than medical. The argument took on a medical aspect because the physicians involved themselves in it. However, James I and others introduced different objections. James had a moral complaint-he considered it to be morally wrong to use tobacco for pleasure. The growth of the practice of so using tobacco had been paralleling the growth of medical practices, the pleasure custom probably having begun as soon as the first seaman had sailed from America smoking a 'medicinal' cigar. James's objection was supported by many who were trying to curry favour with the king. He went beyond his medical and moral complaints and added a complaint about the amount of money that was spent on tobacco. Through proclamations, he tried to curb the use of the herb by imposing a duty on imports and by prohibiting the cultivation of tobacco in England. Tobacco-using dandies in London with their foppery and tobacco-smoking schools were objected to also. ${ }^{51}$

${ }^{40}$ Mullett, pp. 114-18. ${ }^{\text {so }}$ Brooks, Descriptive Notes, p. 31. ${ }^{51}$ Brooks, Descriptive Notes, p. 86. 


\section{A History of the Medicinal Use of Tobacco 1492-1860}

In 1615, Barnaby Rich had said that there were upward of 7,000 apothecaries, grocers, chandlers, and inn-keepers living by the trade of selling tobacco in and near London.

Out of this background, English colonists were sailing for the original home of tobacco across the Atlantic. The record of the medicinal use of tobacco in the early colonies was very scant, one reason being that until about 1650 the colonists had no printing press, and only two or three more had been added by 1700 . Moreover, medicinal use of tobacco was certainly affected by the English controversy. In spite of the reasons that had been advanced for refraining from the use of the medicine, the colonists, if they had not earlier adopted these practices, began at once to use the herb both for medicine and for pleasure. A few European physicians had emigrated with the earliest settlers, but the London argument had not caused them to abandon their practice of prescribing tobacco. This is inferred from the April 1629 First General Letter of the Governor and Deputy of the New England Company for a Plantation in Massachusetts Bay which ordered that the planting of tobacco be suppressed, 'except for meere necessitie'. The same letter forbade the sale of tobacco, or the use of it ' $\ldots$ unless upon urgent occasion for the benefit of health ....$^{52}$ This order was a reflection of what was taking place in England simultaneously.

Because physicians were so few, the Massachusetts Bay colonists looked to Governor John Winthrop for some medical guidance, and he in turn looked to London. In 1643, Dr. Ed. Stafford of London wrote to the governor at Boston about the use of Gerard's herbal, and it is presumed that Gerard's recommendations for the medicinal use of tobacco were followed, for he had said that tobacco would cure 'all of the best known diseases'. ${ }^{.3}$

The colonists would by 1647 certainly have heard more about the London proceedings, for in that year a court order was issued in Connecticut that ' ... noe person ... shall take any tobacco until he hath brought a certificate under the hand of some who are approved for knowledge and skill in physick, that it is useful for him . . . A similar order was promulgated in New Hampshire. ${ }^{54}$

Some time before 1672, John Josselyn, Englishman, visited New England. In his book, An Account of two voyages to New England, published in London in 1674, he reported what he had seen of the colonists' use of tobacco. He observed that the virtues of the plant were:

... it helps the digestion, the gout, the tooth ache, prevents infection by scents, it heats the cold and cools them that sweat, feedeth the hungry, spent spirits restoreth, purgeth the stomach, killeth nits and lice, the juice of the green leaf healeth green wounds, although poison. The syrup for many diseases. The smoke for the Phthisick, cough of the lungs, distillation of rheume, and all diseases of a cold and moist cause, good for all bodies cold and moist taken upon an empty stomach ....

After listing the virtues, Josselyn pointed to some dangers:

... taken upon a full stomach . .. it moderately drieth the body, inflameth the blood, hurteth the brain, weakens the eyes and sinews. ${ }^{\text {s5 }}$

s2 Elizabeth Ramsey, 'The History of Tobacco Production in the Connecticut Valley', Smith College Studies in History, 15, (April-July 1930), pp. 108-9.

ss Francis Randolph Packard, History of Medicine in the United States, New York, 1931, I, 10.

4 Ramsey, p. 111. "s Packard, p. 10. 


\section{Grace G. Stewart}

By 1699, American colonists were using Bate's Dispensary which contained a section on 'Oyl of Tobacco'. The prescription for a purge or a vomit was: 'Anoint the pit of the stomach with gr. $v$ or vi and the patient will presently vomit, but if you would move the body downwards, anoint about the navel therewith and the sick will presently fall a purging'. ${ }^{56}$ Both Josselyn and Bate were merely copying what had already been circulated in Europe.

\section{1-1799}

By 1700 , tobacco was being used more for pleasure than for its medicinal value, both in Western Europe and in the American colonies. It may be said, therefore, that actually the use of tobacco for pleasure, combined with growing distrust of the efficacy of tobacco as medicine, was what began to weaken the structure. It took more than the seventeenth-century debate, however, to do much damage to the panacea of panaceas. The real damage was done in the laboratories of the physicians, the botanists, and the chemists. Of that, more later.

In 1721, William Byrd of Westover, Va., wrote $A$ Discourse Concerning the plague, With some Preservatives Against it. In this discourse, Byrd said that during periods of epidemic, it was a positive obligation to use tobacco, the God-given herb, as a prophylactic. (One wonders how many acres he had planted in tobacco in 1721.) He recommended that the colonists wear tobacco about their clothes and coaches and that they hang bundles of it around their beds. Since Byrd was not a physician, it is probable that he repeated what the English had reported about the use of tobacco during the 1665 bubonic plague epidemic when they had followed the 1572 advice of Dr. Sarassin of Geneva and of later writers in England. The plague that came to Virginia in the eighteenth century was not bubonic, however, but yellow fever. ${ }^{57}$

The historians tell of the colonists of Jamestown planting tobacco as a business enterprise. Since acrid Nicotiana rustica was indigenous to Virginia, John Rolfe had imported seeds of Nicotiana tabacum from Spanish-American plantations in 1611 and had successfully raised the more aromatic species in the Virginia colony. ${ }^{58}$ Part of the crop which the Virginians raised was used by physicians who administered tobacco clysters to their patients, charging as a fee thirty pounds of tobacco. ${ }^{59}$ The Virginians exported some of their crop to England where in 1722 a pamphlet was published advertising the virtues of 'cephalic and ophthalmic snuff' which had been prepared from Virginia tobacco. Virginia was making its own snuff as early as $\mathbf{1 7 3 2 . 6 0}$

In 1655, a book had been published in France dealing with the preparation and the use of snuff for medicinal purposes. ${ }^{61}$ By 1726 , snuff had eclipsed other forms of tobacco medicine in popularity and at that time it was in common use in the American colonies, both for medicine and for pleasure. Shortly before this date, people of finer sensibilities were becoming annoyed at the coarse and shameful eructations and belchings of snuffers, and a small controversy arose in Europe over medicinal snuff, which was also used there for pleasure. Proponents presented case histories to prove that medicinal snuff had cured bronchitis, consumption, apoplexy, and other diseases. Those on the negative side of the debate (which was over by mid-century) had called

${ }_{50}^{56}$ Silvette, $\mathrm{p}_{.}{ }_{4} .{ }^{57}$ Brooks, The Mighty Leaf, $\mathrm{p}_{61} 163 .{ }_{60}^{58}$ Brooks, The Mighty Leaf, pp. 52-53. ${ }^{50}$ Massengill, p. $163 .{ }^{60}$ Fairholt, p. $269 .{ }^{61}$ Brooks, Descriptive Notes, p. 70. 


\section{A History of the Medicinal Use of Tobacco 1492-1860}

the snuffers mere snivellers and snorters; they were digging early graves with their noses. ${ }^{62}$ Cotton Mather, 'angelic conjunction' of physician and clergyman in Massachusetts, made his contribution to the snuff argument when in 1726 he condemned it as a leader to the coffin. ${ }^{63}$ The controversy did have the effect of reducing the quantity of snuff used for medicinal and social purposes, but it did not entirely disappear from medical practice until more than a century later.

Medical books in the colonies were not too plentiful in the eighteenth century, but among those in use was Dodoens' large herbal, Crü̈deboeck which had been recommending tobacco as a sanatory herb ever since 1574. Dr. Alexander Hamilton discovered a Dr. Rosaboom using the large Dutch edition of this herbal in Albany, New York, in 1744. ${ }^{64}$

In 1747, there appeared in England the first of thirty-two editions of Primitive Physick by John Wesley, founder of Methodism. There was a number of American editions of this book, the last one being published in Chicago in 1880, eighty-nine years after Wesley's death. The book had status because John Wesley was another 'angelic conjunction'. He was a licensed practitioner of physic, and he used for his authorities an English pharmacopoeia and Dr. Lewis's materia medica. The only edition of Wesley's work which I was able to examine was that of 1820 published in London, England, and I can only assume that it was similar to the 1747 edition and the later editions which were published in America. Wesley prescribed:

For the ear ache: 'Blow smoke of tobacco into it.'

For falling sickness: 'In the fit blow up the nose . . . leaves of Major's snuff powdered. Or blow down the throat the smoke of tobacco.'

For a nervous headache: 'Take... snuff. This is of great use even in a cancer; but it will suffice to take a small pinch every other night, lying down in bed.'

For killing lice: 'Sprinkle Spanish snuff over the head.'

To cure piles: 'Apply . . . a tobacco leaf steeped in water twenty-four hours."

Wesley's continuing to recommend the medicinal use of snuff so long after the controversy had ended was paralleled by what the doctors of medicine were doing.

In 1753, botanical science was revolutionized when Species Plantarum by Carolus Linnaeus was published at Stockholm. The modern scientific terms for the chief species of the genus Nicotiana, tabacum and rustica, were first included here, and tobacco was thereby definitely classified as a member of the nightshade family (Solanaceae). ${ }^{66}$

The physicians who continued to use tobacco smoke medicinally found two new uses for it. In the Royal American Magazine in February 1774, a Dr. Tissot recommended introducing tobacco smoke into a patient's lungs to resuscitate the apparently drowned. He directed: 'After tobacco has been lighted in the bowl of the pipe, the bowl should be wrapped in a paper in which several holes are pricked and through these holes force the breath strongly'. Some time after 1788, the Humane Society of the Commonwealth of Massachusetts adopted a procedure (which had been followed in Europe since 1671) for using tobacco smoke clysters. This procedure was accompanied by venesection. The apparatus was used to resuscitate the apparently drowned.

${ }^{62}$ Brooks, The Mighty Leaf, p. 131. Brooks, Descriptive Notes, pp. 60-61.

of Gentleman's Progress. The Itinerarium of Dr. Alexander Hamilton, 1744, ed. Carl Bridenbaugh, Chapel Hill, N. C., 1948, p. 67.

os Wesley Hill, John Wesley among the Physicians, London, 1958, pp. 6, 111, 129.

o6 Brooks, Descriptive Notes, p. 4. 


\section{Grace G. Stewart}

The Boston Gazette reported that the system was to blow smoke up the fundament repeatedly. ${ }^{67}$

In 1793 during the yellow fever epidemic in Philadelphia, men, women, and children smoked strong cigars as a prophylactic measure, and tobacco smoke was used to fumigate Philadelphia homes. ${ }^{88}$

In 1798, Philadelphia's Dr. Benjamin Rush wrote Essays, Literary, Moral and Philosophical in which he made observations on the physical dangers of using tobacco. I do not know whether he had medicinal or social uses in mind, however. ${ }^{69}$

By 1799, the use of tobacco in medicine was being abandoned by some United States physicians, and it had been deleted from the materia medica with which a medical student at Philadelphia was familiar. We learn this from Edward Brailsford who in 1799 submitted an inaugural dissertation for the degree of doctor of medicine at the University of Pennsylvania, entitled, Experimental Dissertation on . . . nicotiana tabacum. After lamenting that physicians were abandoning the use of tobacco in medicine, Brailsford said that, having experimented upon himself with liquid decoctions of tobacco, he had come to the conclusion that this plant could be a valuable remedy, and recommended that it be restored to the materia medica. ${ }^{70}$

In South Carolina in the eighteenth century, the sores of yaws and syphilis were washed with tobacco juice, and it has been inferred that smoking had for long been resorted to there as a cure for venereal diseases. ${ }^{71}$

\section{$1800-1860$}

The nineteenth century got under way with a downward pull on the panacea structure by Daniel Legare. Dr. Legare put the final touch upon the practice of injecting smoke into a patient's intestinal canal to resuscitate the apparently drowned, when he presented his inaugural dissertation at the University of Pennsylvania in 1805 , recording the results of his experiments upon animals with the rectal insufflation of tobacco smoke and demonstrating thereby that this mode of procedure was of no value as a means of resuscitation. ${ }^{72}$ The discontinuance of the practice of using tobacco smoke for this particular purpose did not mean that physicians abandoned the practice for other purposes, however, for it was continued until 1860 and possibly later.

More laboratory work was soon to prove very damaging to the panacea structure. In 1809, a French chemist, Louis Nicholas Vauquelin, discovered, but was not able to isolate completely, the active principle of tobacco, which he called Nicotianine. Following Vauquelin's discovery, analysts pursued their work until 1828 when L. Posselt and F. A. Reimann at Lille, France, isolated the constituent of the tobacco plant now called nicotine, ${ }^{73}$ the chemical formula for which is $\mathrm{C}_{10} \mathrm{H}_{14} \mathrm{~N}_{2}$. The name assigned to the poisonous alkaloid, nicotine, perpetuated the name of Nicot.

As soon as nicotine had been isolated, physicians should have pushed the tottering panacea structure over and have been done with the tobacco treatment. Since they did not demolish the building at once, but rather let it fall slowly, I can only refer

67 J. Collins Warren, 'The "Pulmotor" of the Eighteenth Century', Ann. Med. Hist., 1918, $2,17$.

se Benjamin Lee Gordon, The Romance of Medicine, Philadelphia, 1949, p. 419.

9 Brooks, The Mighty Leaf, p. 219. ${ }^{70}$ Brooks, Descriptive Notes, pp. 78-79.

7 Silvette, p. 12. 72 Warren, p. 18. 73 Brooks, The Mighty Leaf, p. 281. 


\section{A History of the Medicinal Use of Tobacco 1492-1860}

to my hypothesis that the effect of the addictive property of nicotine was what kept the physicians using it as medicine. Physicians are very sympathetic persons, and it is only natural that they should have continued to prescribe dosages of a medicine that alleviated pain, especially when they had no known cure.

In 1958, a significant contribution to the history of the medicinal uses of tobacco was made by H. Silvette, Ph.D., P. S. Larson, Ph.D., and H. B. Haag, M.D., at the Department of Pharmacology, Medical College of Virginia. In their study, they traced the record, chiefly through medical periodicals, beginning in 1762 and continuing into the twentieth century. They show how frequently tobacco was a subject for discussion and how it grew in popularity as a subject as the century advanced. I analyzed the doctors' study (Appendix No. 12, page 264) showing the outcome of varieties of treatment which they had recorded in case reports from 1785 to 1860 . The reports included cases treated in Eire, England, France, Germany, Italy, Scotland, and the United States. A few notes on the analysis will suffice.

A partial breakdown of the outcome of the 128 cases reported follows:

$\begin{array}{lr}\text { Successful } & 97 \\ \text { Fatal } & 4 \\ \text { Poisoning } & 10 \\ \text { Other outcome } & 17\end{array}$

In addition to those reported earlier, the doctors categorized thirty diseases and other conditions as being treated with tobacco in the United States between 1800 and 1860. New compounds using tobacco in this country included: aetherial tincture, cataplasms, snuff plasters, and poultices.

Among the instruments used to administer tobacco medication parenterally, newly reported in the United States in 1830, was the introduction of tobacco by injection into the vagina of a female patient to treat tetanus, successfully. In the year 1849, Dr. Robert B. Todd exposed this kind of success when he wrote that treating tetanus with tobacco was neither safe nor manageable and that he had seen more than one patient 'cured' of tetanus die under the use of this remedy. ${ }^{74}$

From the summary of the Silvette article, the conclusion might be drawn that there was an increase in the nineteenth-century use of tobacco as medicine as compared with the amount in the eighteenth century. I believe that there was an obtuseness present in the physicians' continuing to experiment with the plant after the discovery of nicotine in 1828, but I hardly think that the variety or the volume of applications increased, for the following reason. In the eighteenth century there were few medical journals being published. Moreover, nomenclature and diagnosis were not accurate, nor were carefully kept case histories the rule. This, I think, would explain the little that was reported. In the nineteenth century, the art of medicine had advanced to the stage where there was greater knowledge of pathology, and nomenclature and diagnosis were more nearly accurate, while carefully kept case histories were the rule. This advance, with the increasing number of medical journals, provided historians with both ample and accurate sources to draw upon, which probably accounts for the apparently greater nineteenth-century use of medicinal tobacco.

The wonder of the Silvette report is that the physicians were so loath to proscribe

"Brooks, The Mighty Leaf, p. 39. 


\section{Grace G. Stewart}

tobacco therapeutics in the face of their knowledge of the nicotine content of tobacco and also in the light of their advanced knowledge of anatomy, pathology, and diagnosis. It is almost unbelievable that diseases and other conditions bearing such modern names as those in the Silvette therapeutic index, listed by body systems, should have been treated with what was known to be so injurious a remedy. The tobacco smoke clyster was in the materia medica to mid-nineteenth century, and the use of it in the United States up to and beyond 1860, to treat strychnine poisoning, intussusception, strangulated hernia, ileus, and hydrophobia is evidence of the kind of medical error to which the human body was subjected at that time.

In 1838, Lobelia inflata was being supplied to physicians as a drug for treating cases of spasmodic asthma. This was a false name for aetherial tincture of tobacco, and one physician wrote that he had frequently employed it before he discovered the artifice.

In the three decades from 1830 to 1860 , a group of noted American educators, some members of the clergy, a few physicians, and others maintained a steady solemn attack upon tobacco, not all of it directed at the medicinal use of the weed. (There was a similar attack in Europe also on which no comment is made here.) The opposition ranged from temperate advice to passionate denunciation. Dr. Joel Shaw traced delirium tremens, perverted sexuality, impotency, insanity, and cancer to the effects of tobacco. He, of course, was writing of the social use of the plant. One of the most ardent anti-tobacco physicians was Dr. R. T. Trall who wrote Tobacco, Its History, Nature, and Effects, in 1849, in which he pictured the sufferings of a confirmed addict deprived of tobacco. Although this addict had probably become so by using tobacco for pleasure, Dr. Trall's medical account is given because it is a description that would apply equally to one who had become addicted to its medicinal use. 'All through the long night do these fiends [ghosts of tobacco] of a disordered nervous system play their fantastic tricks to his torment; and as the morning dawns, the wretched victim of a miserable habit feels utterly prostrated; and although he may still be determined to persevere in his abstinence and suffer through, he finds it almost impossible to think of anything but Tobacco; while every perverted, enraged, and rabid instinct is crying out, "A quid! a quid! My kingdom for a quid". 75

By mid-nineteenth century, tobacco had almost disappeared from the U.S. Pharmacopoeia, and by 1851 the potential dangers of tobacco as a drug were well known.

In the year 1851, a book amounting to a summation was published in Boston by L. B. Coles, an anti-tobacco physician. He called his work Beauties and deformities of tobacco-using or its ludicrous and solemn realities. Dr. Coles singled out the addictive property of tobacco, although not so designating it. He said that tobacco was never taken like other medicine and then laid aside. 'A man takes this so-called medicine for forty years perhaps, but gets no cure'. He cited many case histories to prove that tobacco never cured certain diseases for which it was prescribed. He also wrote of the harmful effects of 'narcotine', other than addiction. He said that tobacco had often been prescribed where the remedy was infinitely worse than the disease and, as proof, he illustrated with case histories of tobacco's causing fatalities and life-long

${ }^{75}$ Brooks, The Mighty Leaf, pp. 219-21. 


\section{A History of the Medicinal Use of Tobacco 1492-1860}

injuries. Its use by mouth, Dr. Coles said, was in about all cases uncalled for, inexpedient, and even morally wrong. But even he had some reservations as he pummelled away. A wet leaf might be introduced into the extremity of the bowel in case of obstinate colic because tobacco was fit for the fundament but not for the mouth. In saying that tobacco was fit for the fundament, it is clear that Dr. Coles was holding the hope that tobacco was still useful for treating some conditions. He echoed the very earliest writers on medicinal tobacco when he wrote, 'Tobacco, doubtless, with other kindred poisons, was intended for medicinal purposes'.

By 1860 , physicians had pretty generally begun to abandon the use of tobacco as medicine, and for all practical purposes it can be said that the panacea structure had fallen. The chief factor contributing to the fall was, of course, the discovery of nicotine. Added to this was the medical profession's recognition of the fact that nicotine not only was poisonous but that it produced addicts as well as life-long injuries and fatalities.

\section{SUMMARY AND CONCLUSION}

Botanists believe that the tobacco plant has been growing in the area now known as the United States ever since that far distant day of creation when its Maker placed it there. In this paper, we began tracing the history of the medicinal use of the herb in the Americas from the year 1492. By 1536, it was recognized that tobacco had a narcotizing and an addictive property. Due to the work of well-meaning propagandists, who carried news of the plant to Western Europe, physicians brought their doctrine to the stage where by 1600 tobacco was saluted as the panacea of panaceas, and Europeans were then using it habitually for treating every kind of human ill. The inordinate claims of the panaceists caused some honest doubters to wage a controversy in Europe over the medical value of tobacco. The debate in London lasted from 1602 to approximately 1665 . Opponents denied that tobacco was a catholicon, and the result was that the use of the plant as medicine began to wane.

Meantime, beginning in 1607, English colonists had started to settle in the New World where they used medicinal tobacco for 'meere necessitie', and eventually they were also using medicinal snuff extensively.

Early in the eighteenth century, a controversy arose in Europe over medicinal snuff. This dialogue, ending about 1750 , had the effect of decreasing the use of medicinal snuff.

Chemists in Europe isolated nicotine, the principal constituent of tobacco, in 1828 , and as a result of the certain knowledge of the presence of poison in tobacco, a dispute started over tobacco medicine in the United States which continued from about 1830 until about 1860 . Physicians were critical of the use of tobacco for medicine (and for pleasure), giving as a reason (among others) its addictive property. By 1860, little remained of the panacea-of-panaceas doctrine, for tobacco had been, for all practical purposes, abandoned for medicinal use.

During the period when the herb had been prescribed as a panpharmacon, it had not actually cured disease. The best that could be said of it was that in many cases tobacco had alleviated pain, and it was for this reason that Americans found it hard to free themselves of their addiction to its use. 


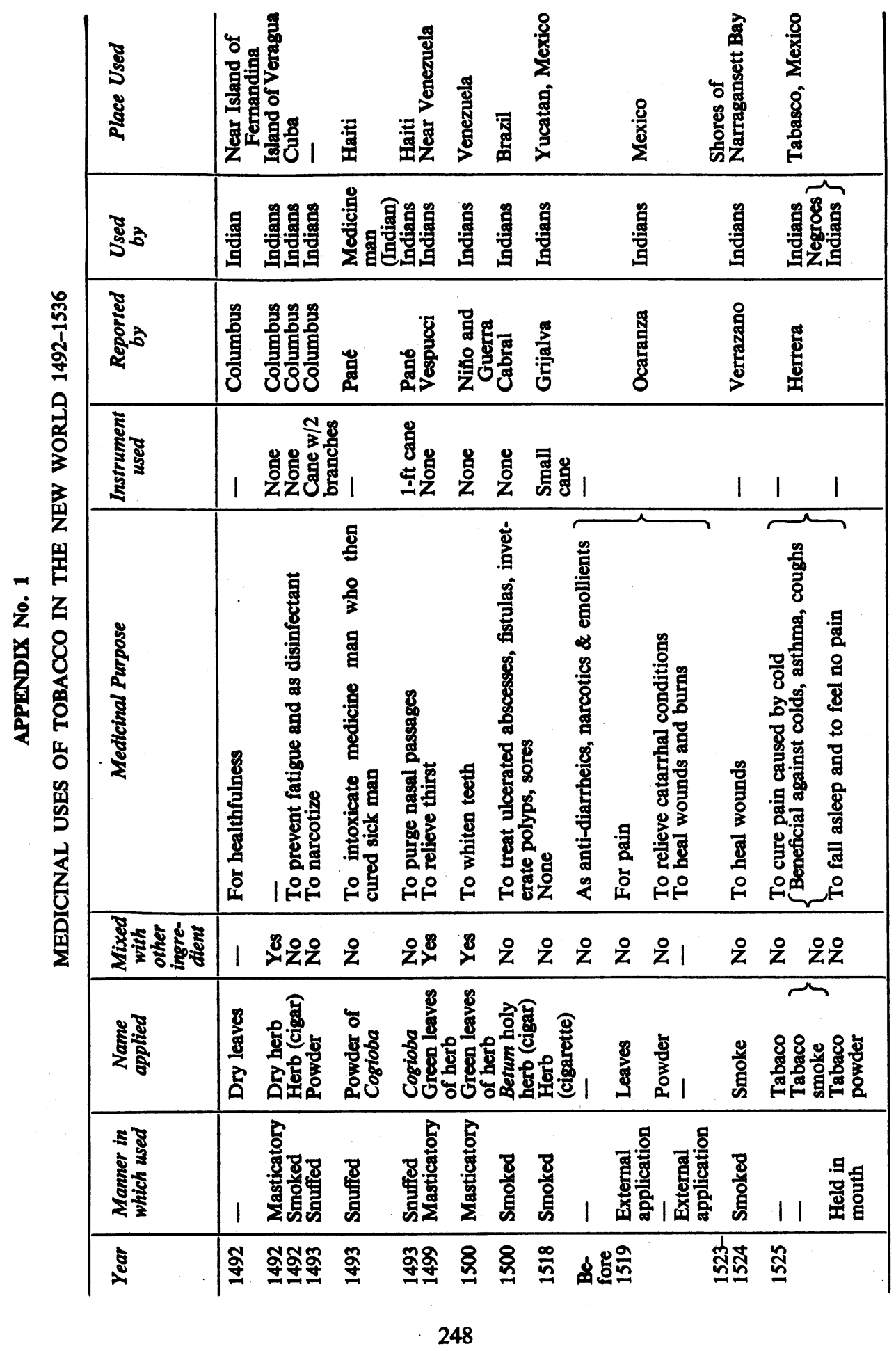




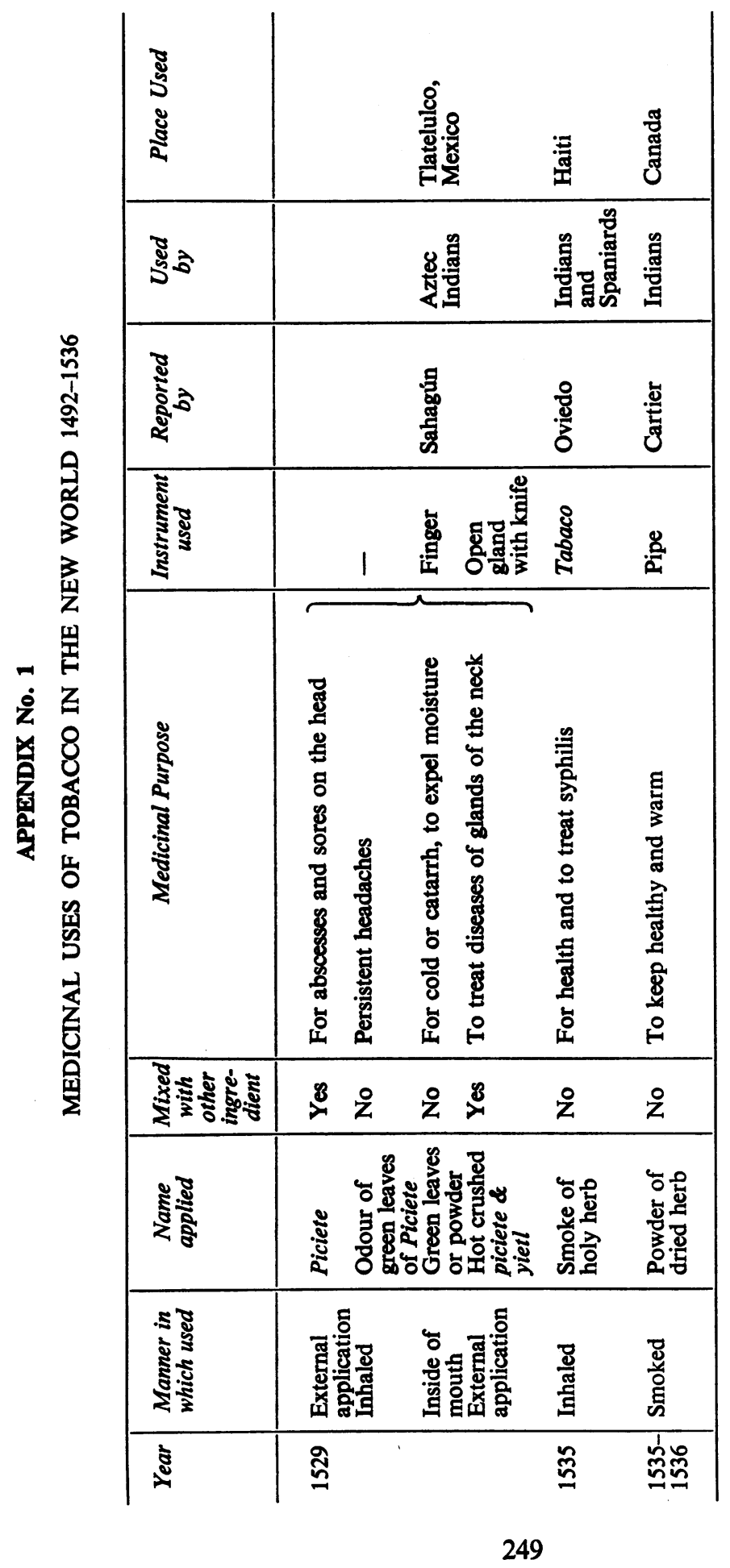




\section{Grace G. Stewart}

\section{APPENDIX No. 2}

BOOKS MENTIONED IN WORKS CONSULTED WHICH REFER TO MEDICINAL USE OF TOBACCO, CHRONOLOGICALLY ARRANGED, 1503-1665

(except those in the seventeenth-century controversy)

1503 VesPUCCI, AMERIGo, Mundus novus, Florence.

1504 NiÑo, ALONSO, Libretto de tutta la nauigatione de re de Spagna de le isole et terreni nouamente trouati, Venice.

1505 VespuCCI, AMERIGo, Lettera di Amerigo Vespucci delle isole nuovamente trouate in quattro suoi viaggi, Florence.

1507 Waldsebmüller, Martin, Ringmann, Mathias, Basin, Jean, collaborators, Cosmographiae introdvctio cvm quibvsdam geometriae ac astronomiae principiis ad eam rem necessariis insuper quatuor Americi Vespucij nauigationes, St. Dié.

1511 MartYr, Peter (Anghiera, Pietro Martire d'), P. Martyris, ab angleria mediolanensi. Opera. Legatio Babilonica. Oceanea decas. Poemata, Seville.

1516 De orbe novo Decades, Alcalá de Henares.

1520 BOEMUS, JOANNES (of Ulm), Omnium gentium mores, leges et ritus.

1524 Verrazano, GIOvanNI DA, Account of travels sent to Francis I of France in French, with copies in Italian.

1534 MARTYR, Peter, P. Martyris, ab angleria mediolanensi. Opera. Legatio Babilonica. Oceanea decas. Poemata. Trans. by Michael Herr into German.

1535 OVIEDO Y VALDEs, GONZALO FERNÁNDEZ DE, La historia general delas Indias, Seville.

1542 CABeça de VaCA, Alvar Nữez, La relacion, Zamora.

1545 CARTIER, JACQUES, Brief recit, \& succincte narration, de la nauigation faicte es ysles de Canada, Hochelage \& Saguenay.

1550 Cardano, Girolamo, De subtilitate libri $X X I$.

1550 NÓBREGA, MANOEI DE, Letter to Father Simao Rodriquez from Brazil.

1550-1559 RAMUSIO, GIOVANNI BATTISTA, Delle navigationi et viaggi, Venice.

1552 CRUZ, MARTINUS DE LA, Libellus de medicinalibus Indorum herbis Trans. by Joannes Badianus from Nahuatl. Tlaltelulco, Mexico.

1552 LóPEZ de GÓMARA, Francisco, Historia general delas Indias.

1553 DODOENS, REMBERT, Trium priorum de stirpium historia commentariorum imagines ad viuum expressae, Antwerp.

$1554 \longrightarrow$, Cruÿdeboeck, Antwerp.

1555 Martyr, Peter, P. Martyris, ab angleria mediolanensi. Opera. Legatio Babilonica. Oceanea decas. Poemata. Trans. into English by Richard Eden and titled The Decades of the newe worlde, London.

1556 Thamara, Bachiller Francisco, El libro de las costumbres de todas las gentes del mundo, y de las Indias, Antwerp.

1557 Cardano, Girolamo, De rerum varietate, Basle.

1557 Barre, Nicolas, Copie de quelques letres sur la navigation du Cheuallier de Villegaignon es terres de l'Amerique oultre l'AEquinoctial, Paris.

1557 DODOENS, REMBerT, Cruÿdeboeck. Trans. by Charles de I'Écluse into French.

1557 THEVET, ANDRE, et al, Les singularitez de la France antarctique.

1558 LóPEZ DE Gómara, Francisco, Historia general. Trans. into Italian and titled: Gli costumi, le leggi, et l'usanze di tutte le genti . . aggiuntovi . . gli costumi, \& usanze dell' Indie Occidentali, Venice.

1561 Thevet, ANDRE, Les singularitez. Trans. into Italian by Guiseppi Dondi dall' Orologio and titled: Historia dell' India America detta altramente Francia antarctica.

1562 Mattioli, Pietro Andrea, Commentary on the materia medica of Dioscorides, Bohemian edition.

1562 Nóbrega, Manoel de, et al., Nuovi avisi dell' Indie di Portogallo. Terza Parte, Venice.

1563 DODOENS, REMBERT, Crujydeboeck. Second edition of Dutch herbal of 1554.

1563 Mattioli, Pietro Andrea, New Kreüterbuch, German edition, Prague.

1563 WEYER, JOHANN, De praestigiis daemonum, Basle.

1565 Benzoni, Girolamo, La historia del mondo nuovo, Venice.

1565 Mattiol, Pietro Andrea, Commentarii in sex libros Pedacii Dioscoridis Anazarbei de medica materia, Venice.

1565 Monardes, Nicolás, Dos libros El vno trata de todas las cosas q[ue] traē de nüas Indias Occidēntales, que sirven al vso de Medicina . . . El otro libro, trata de dos medicinas marauillosas $q[u e]$ son cötra todo veneno, Seville.

1566 Goes, DAMIÃo DE, Chronica do felicissimo Rei Dom Emanuel (Primera Parte), Lisbon.

1567 BENAVIDES, PEDRO ARIAS DE, Secretos de Chirurgia, Valladoid.

1567 Estienne, Charles, and Jean Likbault, L'Agriculture et maison rustique, Paris.

1568 THEVET, ANDRE, Les singularitez. Trans. into English by Thomas Hacket, titled The new found worlde. London.

1570 Estienne, Charles and Jean Líbault, New edition of L'Agriculture et maison rustique. 


\section{A History of the Medicinal Use of Tobacco 1492-1860}

1570-1571 L'Obel, MatThias De and Pena, Pierre, Stirpium adversaria nova, London.

1571 Colombo, Fernando, Historie . . . dell' Ammiraglio D. Christoforo Colombo.

1571 Molina, Alonso DE, Vocabulario en lengua Castellana y Mexicana, Mexico.

1571 MONARDES, Nicolás, Segunde parte del libro, de las cosas que se traen de nuestra Indias Occidentales, Seville.

1571 OsorIo, BIshop GeronYmo, De Rebus, Emmanuelis Regis Lusitaniae invictissimi virtute et auspicio gestis libri duodecim, Lisbon.

1572 BENZONI, GIROLAMO, La historia del mondo nuovo. New Italian edition of 1565 publication.

1572 Estienne, CharLes and JEAN LikBaUlt, L'Agriculture et maison rustique. New edition of 1567 publication, Paris.

1572 FRAGoso, JuAN, Discursos de las cosas aromaticas, arboles y frutales . . que se traen de la India Oriental, Madrid.

1572 GOHORY, JAOQUES, Instruction sur l'herbe petum, Paris.

1572 HernánDez, Francisco, Letters to King Philip II of Spain from Mexico City.

1572 SARRAsin, ANTOINe, De peste commentarius, Lyons and Geneva.

1573 Nicot, JeAn, Dictionaire Francois-Latin, Paris.

1574 DODOENS, REMBERT, Purgantium aliarumque eo facientium tum, et Radicum, Conuoluulorum ac deleteriarum herbarum Historiae Libri IIII, Antwerp.

1574 Monardes, Nicolás, Primera y secunda y tercera partes de la historia medicinal de las cosas que se traen de nuestras Indias Occidentales, Seville.

1574 Estienne, Charles and Jean Libault, L'Agriculture et maison rustique. New printing.

1575 MONARDES, Nicolas, First two parts of Monardes' works above translated into Italian by Annibal Briganti, titled Delle cose ... dall' indie occidentali, Venice.

1575 TheVET, ANDRE, La Cosmographie universelle, Paris.

1576 L'OBEL, MATTHIAs DE, Plantarum seu stirpium historia.

1576 , Stirpium adversaria nova. Subsequent issue of 1570-71 edition.

1577 GESNER, CONRAD, Epistolarum medicinalium . . . libri III, Zurich.

1577 MARTYR, PETER, First portion of P. Martyris translated into English by Richard Eden, titled The History of Travayle in the West and East Indies. Ed. by Richard Willes.

1577 MONARDEs, NicoLAs, Three books of Monardes (above) translated into English from Spanish ed. of 1574, titled Ioyfull Newes out of the newe founde worlde, John Frampton, translator, London.

1578 BENZONI, Girolamo, La historia del mondo nuovo, Latin translation made by Urbain Chauveton.

1578 DODOENS, REMBERT, English version of Cruj̃deboeck.

1578 LERY, JEAN DE, Histoire d'un voyage fait en la terre du Brésil, La Rochelle.

1578 LYTB, HENRY, English version of Dodoens's great Dutch herbal of 1554 titled A niew Herball, or Historie of Plantes (Translated from Charles de l'Écluse's French translation of the herbal).

1579 BENZONI, GrROLAMO, French ed. of La historia del mondo nuovo pubd. 1565, Urbain Chauveton, translator. Venice.

1579 German version of La historia del mondo nuovo.

1579 Estienne, Charles and Jran Libbault. Pirated ed. of Geneva ed. of La maison rustique.

1579 MELCHOR SEBISCH published an ed. of the 1574 issue of $L a$ maison rustique titled Siben Bücher von dem Feldbau in German. Strassburg.

1579 L'ÉCLUSR, CHARLES DE, Simplicium medicamentorum, Antwerp.

1579 MONARDES, NicOLAs, First two works which had been translated into Latin in abridged form and provided with useful notes by Charles de l'Écluse, 1574, reprinted.

1580 CARTIER, JACQUEs, John Florio's translation of an account of Cartier's two voyages issued in English.

1580 MonARDes, Nioolas, Three books of Monardes translated from Spanish ed. of 1574 by John Frampton and issued in English under title Ioyfull Newes out of the new founde worlde, in 1577, appeared again.

1581 BENZON, GIROLAMO, La Historia del mondo nuovo, Latin translation made in 1578 by Urbaiu Chauveton reprinted.

1581 DURÁN, FrAY DIRGO, History of Mexico manuscript, second section.

1581 L'OBEL, MATTHIAS DE, Icones stirpium seu plantarum tam exoticarum quam indigenarum, Antwerp.

1581 , Two herbals by De l'Obel incorporated into one, translated into Dutch and published by Plantin under title Kruydtboeck.

1582 Benzon, GrRolamo and MarTyr, PeTER, Another German ed. of P. Martyris, together with the second German ed. of Benzoni's Historia del mondo nuovo, titled Der Newen Weldt und Indianischen nidergängischen Königreichs newe vnd wahrhaffte History, Basle.

1582 FIORAVANTi, LeONARdo, Della fisica, Venice.

1582 MONARDES, Nicolás, First two parts of Monardes' works translated into Italian by Annibal Briganti, published again.

1582 REUSNER, JeREMIAS, Decisiones praecipuorum aliquot .... (dissertation, academic), Basle.

1582 Verrazano, GiovanNi DA, Richard Hakluyt's English translation of Verrazano's report. Translation title: Divers voyages touching the discouerie of America, London. 


\section{Grace G. Stewart}

1583 Cesalpino, Andrea, De plantis libri XVI.

1583 DODOENS, REMBERT, Stirpium historiae pemptades sex.

1583 ESTIENNE AND LIÉBAULT, Another ed. of L'Agriculture et maison rustique.

1583 WEYER, JOHANN, De praestigiis daemonum, reprinted.

1584 THEVET, ANDRE, Les singularitez of 1557 as translated by Thomas Hacket in The new found worlde in 1568 translated into Italian by Guiseppe Dondi dall' Orologio, titled Historia dell' India America detta altramente Francia antartica.

1585 Bonardo, Giovanni Maria, La minera del mondo, Venice.

1585 Durante, Castore, Herbario Novo ...

Not long after

1585 CARDIM, FERnão, Manuscript of Treatise of Brasil.

1586 ALECHAMPS, JACQUES D', Historia generalis plantarum, finished by Jean Desmoulins. Also called Historia plantarum Lugdunensis, regarded as joint publication of botanic fraternity of Lyons, Lyons.

1586-1587 HARRISON, WIILIAM, Ralph Holinshead published Harrison's Description of England in $A$ whole volume of chronicles.

1586 LERY, JEAN DE, Histoire d'un voyage ... translated into Latin titled Historia navigationis in Brasiliam.

1586 Mattioli, Pietro ANDrea, Latin ed. of Mattioli's work, edited by Joachim Camerarius $D e$ Plantis Epitome utilissima Petri Andreae Matthioli, Frankfurt-am-Main.

1586 WEYER, JOHANN, German translation of 1583 ed. of De praestigiis daemonum published in 1563, Frankfurt-am-Main.

1587 EVERAERTS, GILlES, De herba panacea, Antwerp.

1587 SoARes De SousA, Gabriel, Manuscript, Treatise on Brazil.

1588 Camerarius, JoACHIM, Hortus medicus. Took material from Konrad Gesner's comprehensive history of plants (never published).

1588 ClOWES, WILLIAM, A prooued practise for all young chirurgians, concerning burnings with Gunpowder, and woundes made with Gunshot, Sword, Halbard, Pyke, Launce, or such other.

1588

1588

1589

1589

1589

1590

HARIOT, THOMAS, $A$ briefe and true report of the new found land of Virginia.

TheODOR, JAKOB, First vol. Neuw Kreuterbuch, with second vol. issued by Nicolaus Braun, Frankfurt-am-Main.

of medicines that commonly fal into the Chyrurgions vse, London.

HaRIoT, ThOmas, Hakluyt included Hariot's Briefe and true report . . . in his Voyages.

SPARKE, JOHN, Sparke wrote 1564-1565 an account of the voyage of Sir John Hawkins to the Coast of Guinea, and the Indies of Noua Spania which Richard Hakluyt published in his Voyages.

AcostA, JosE DE, Historia natural y moral de las Indias, Seville.

BENZONI, GIROLAMO, Latin translation of La Historia . . . made in 1578 by Urbain Chauveton reprinted.

HaRIOT, THOMas, $A$ briefe and true report . . . published in 1588, included as Part I of Theodore De Bry's Great Voyages.

_- Admirando narratio, Latin ed. of Hariot's Briefe and true report, Frankfurt-am-Main. Frankfurt-am-Main.

SPENSER, EDMUND, The Faerie Queene, London.

Braun, Nicholaus, Second volume of Neuw Kreuterbuch of 1588 by Jakob Theodor issued 1591 and reprinted until 1721.

CÁRDENAS, JUAN DE, Primera parte de los problemas y secretos marauillosos de las Indias, Mexico.

Le MoYne de Morgues, JAcQues, Theodor De Bry used Le Moyne's account of the Florida colony written in 1584 in Latin version Brevis narratio eorum quae in Florida Americae provincia Gallis acciderunt, Frankfurt-am-Main.

L'OBEL, MATTHIAS DE, Icones stirpium seu plantarum tam exoticarum quam indigenarum republished, Antwerp.

StaDen, Hans, Warhaftige Historia und beschreibung eyner Landtschafft der Wilden Nacketen Grimmigen Menschfresser Leuthen in der Newenwelt America gelegan translated into Latin.

ROSACCIO, GIUSEPPE, Inestimabile et maravigliosa virtu del Tabaco, Vicenza.

CHUTE, ANTHONY, Tabaco. The distinct and seuerall opinions of the late and best Phisitions that haue written of the diuers natures and qualities thereof, London.

BAUHIN, KASPAR, . . . seu enumeratio plantarum, Basle.

Plat, HUGH, Sundrie new and artificiall remedies against Famine, London.

ClOWES, WILlLAM, A profitable and necessarie Booke of Obseruations.

MONARDES, NICOLAs, Ioyfull Newes out of the New founde world (Translation from Spanish to English), London.

GERARD, JOHN, The Herball or generall Historie of Plantes, London.

BASTARD, Thomas, Chrestoluos. 


\section{A History of the Medicinal Use of Tobacco 1492-1860}

1598 BaUHIN, KASPAR, Bauhin's edition of the herbal of Mattioli, Opera quae extant omnia: hoc est, Commentarii in VI. libros Pedacii Dioscoridis Anazarbei de Medica materia, Frankfurtam-Main.

1598 FLORIO, JOHN, $A$ worlde of Wordes, London.

1598-1600 HAKLUYT, RICHARD, The principal navigations, voyages, traffiques and discoveries of the English Nation (Second ed. of his Voyages).

1598 Davies, SIR JoHN, Epigram to 'Silla' No. 36. Published by Christopher Marlow under title: Epigrammes and Elegies, by I. D. and C. M., Middlebourgh.

1599 BUTTES, HENRY, Dyets dry dinner, London.

1599 Camerarius, Philipp, Operae horarum succisivarum sive med tationes historicae.

1599 GERARD, JOHN, Catalogus arborum, fruticum ac plantarum tam indigenarum, quam exoticarum, London.

1599 Platter, Thomas, The Younger, Manuscript of account of his stay in England (At Univ. of Basle).

1600 VAUGHAN, WILLIAM, Naturall and artificial directions for health, London.

1601-1615 HERRARA Y TORDESILlAs, ANTONIO DE, Historia general de los hechos delos castellanos, Madrid.

1605 Pena, Pierre and L'Obel, Matthias De, Adversaria of 1570/71 reissued, Dilucidae simplicum medicamentorum, London.

1615 HeRnÁNDEZ, FranCisco, Three books of foreign plants abridged and edited by NardoAntonio Recchi and translated into Spanish by Francisco Ximenes, titled Quatro libros de la naturaleza, $y$ virtudes de las plantas, Mexico.

1621 MEER, WILLEM VAN DER, Letter to Johann Neander.

1622 NeANDER, Johann, Tabacologia, Leyden.

1625 BRADWELL, STEVEN, $A$ watchman for the Pest.

1625 Purchas, Samuel, Purchas his Pilgrimes, London, Vol. IV., includes Treatise of Brasil written by Portuguese Father Fernão Cardim.

1625 The Red-Crosse; or Englands Lord have mercy upon us.

1625 THORIUS, RAPHAEL, Hymnus tabaci, Leyden (was circulating in manuscript form about 1610).

1636 BEVERWYCK, JOHAN VAN, Schat der Gesontheydt, Amsterdam.

1639 Primrose, JAMrs, 'Caution against using tobacco therapeutically'.

1648 Magnen, Johann Chrysostom, Exercitationes de tabaco, Pavia.

1665 HARVEY, DR. GIDEON, $A$ discourse of the plague.

\section{APPENDIX No. 3}

\section{DISEASES AND OTHER CONDITIONS (MENTIONED IN WORKS CONSULTED), FOR WHICH TOBACCO WAS USED THERAPEUTICALLY 1492-1860}

Abdominal pains, 1519, 1525, 1571, 1579, $1601,1711,1838$.

Abscesses, 1500, 1529, 1571.

Aches, any part of body, 1571, 1597, 1610.

Agues, 1633, 1682.

Ailments, 1550, 1571, 1579, 1586, 1591, 1749.

Apoplexy, 1614, 1668, 1711 .

Apostemes, 1597.

Arthritis, 1614, 1746.

Asthma, 1525, 1560, 1571, 1574, 1601, 1610, $1614,1617,1622,1633,1724,1838$.

Biliousness, 1744.

Bites, mad dog, 1622.

Poisonous insects and reptiles, 1571, 1598, 1860.

Bloody flux, 1622.

Bodily ills, 1550.

Body, all disorders, 1749.

Boils, 1610.

Botches, 1597, 1610.

Brain, to consume and spend gross and slimy humours from the ventricles, 1610.

Continual senselessness or benumbing, to relieve, 1610,1711 .

Purges, 1622.
Breast, ache, grief, imposture or obstruction proceeding of cold, 1599.

Rottenness of 1571 .

Breath, bad, 1571, 1595, 1599, 1614.

Breathing, difficulties in, 1500, 1571, 1614.

Bronchitis, 1668.

Bruises, 1633.

Bubonic plague, 1610, 1622.

Sores of, 1572.

Preventive against, 1625, 1636, 1646, 1665, 1672.

Burns, 1519, 1595, 1597, 1622, 1633.

Cancer, 1622, 1747.

Cancerous growth and sores, 1560, 1567.

Canker, 1617.

Carbuncles, 1571, 1595, 1622.

Cataracts, 1622.

Catarrh, 1519, 1529, 1550, 1599, 1621, 1711, 1830.

Chest, afflictions, 1560.

ailments, 1570.

pains of and to expel matter from, 1571.

phlegm and rottenness, impurities and moisture, 1574.

Chilblains, 1571. 


\section{Grace G. Stewart}

Children, to prevent birth of weak, 1690 .

Colds, 1529, 1550, 1595.

Cold, pain and dampness, 1550.

Colic, 1614, 1622, 1682, 1785, 1813, 1851.

Constipation, 1633, 1762, 1830, 1858, 1860.

Consumption, 1610, 1617, 1633, 1668.

Corns, 1622.

Coughs, 1525, 1595, 1601, 1614, 1622, 1633, 1674,1724 .

Croup, 1828.

Cutaneous insects, to eliminate, 1851.

Cuts, 1560, 1571, 1595, 1597, 1621.

Deafness, 1597, 1622, 1711.

Defluxion, 1830.

Delirium, to restore to senses (no date given).

Dermatitis, 1860.

Diarrhoea, 1519.

Digestion, aid to, 1550, 1621, 1674.

Diseases, engendered in inward parts, 1573, 1586.

Of cold and moist cause, 1674.

Dizziness, 1614, 1633.

Dropsy, 1571, 1602, 1622, 1633, 1785, 1840.

Drunkenness, to cause, 1574.

To cure, 1598.

Dysentery, 1622.

Ear ache, 1622, 1747.

Ears, to open, 1614.

Effusions of blood, 1591.

Emrods, 1622.

Epilepsy, 1614.

Erysipelas, 1598.

Eyes, to evacuate offending humours from, 1722.

Soreness in, 1711.

To improve sight, 1614.

To cleanse (date not given).

Face, redness, 1597, 1622.

Falling sickness, 1711, 1747.

Female trouble, 1622.

Fevers, 1552, 1582, 1615, 1659.

prophylactic against yellow fever, 1793.

Finger nails, to regrow, 1595.

Fistulas, 1500 .

Fits of the mother, 1571, 1597.

Flatulence, 1633.

Gangrene, 1500, 1571, 1633.

Giddiness, 1711.

Gout, 1571, 1597, 1610, 1614, 1622, 1674, $1836,1843$.

Gravel, to prevent, 1614.

Hair, to stop falling, 1622.

To promote growth, 1838.

Head, afflictions of, 1560 .

any griefe, imposture or obstruction proceeding of cold, 1599.

To clear, 1622.

Cuts of, 1633.

Diseases in, 1749.

Disorders of, 1711.

To evacuate offending humours from, 1722.

Griefes of, 1610.
Head, afflictions of, cont'd

Griefes of cold causes, 1571.

Hurts of, 1597.

Infirmities of, 1591.

Lethargy of, 1610.

Pains of, 1571, 1597, 1610, 1633.

Sores on, 1529.

Vertiginy of, 1610.

Headaches from common cold, 1571.

Megrim, megram, migraine, megrain, 1571, $1614,1633$.

Nervous, 1747.

Healthfulness, to produce, 1492, 1535.

Heels, kibed, 1633.

Hemicrania (no date given).

Hemorrhoidal bleeding, to stop, 1838.

Hemorrhoids, 1846.

Hernia, 1823, 1839, 1848, 1850, 1858, 1859.

Hoarseness, 1599.

Humours, 1550, 1610, 1623, 1665.

Hunger, preventive against, 1457, 1465, 1470 , $1557,1565,1570,1571,1585,1591,1597$. 1674.

Hydropsie, 1614.

Hysteria, 1842.

Ileus, 1857, 1859, 1860.

Indigestion, 1599.

Inebriation, to produce, 1550, 1574.

Infection, 1567.

Prophylactic against, 1595, 1674.

Injuries, 1567.

Intestinal worms, to eliminate, 1571, 1595, 1597, 1610, 1633, 1762.

Intussusception, 1839.

Itch, 1617.

Joints, pains of, 1571.

Kidneys, diseases of, 1571, 1599.

King's evil, 1560, 1595, 1617.

Labour pains, to facilitate, 1633.

Lapsus uvulae (no date).

Laryngeal spasm, 1828.

Lice, to kill, 1674, 1747.

Liver obstructions, 1633.

Lungs, ache of, 1599.

Diseases engendered in, 1573, 1586.

Wasting of, 1570.

Madness, 1571.

Malaria, 1851, 1852.

prophylactic against, 1844, 1845.

Mammary engorgement (no date).

Mangy diseases, 1682.

Melancholy, hypochondriac, 1614.

Memory, to improve, 1622.

Merri galles, 1633.

Mind, disorders of, 1749.

To be put out of, 1574

Moisture, to expel from head, 1557, 1570.

Mucous, to remove from mouth, 1567.

Murmur ventris, 1552.

Muscle contracture, 1848.

Narcotization, to produce, 1493, 1525, 1529 , $1552,1559,1570,1585$. 


\section{A History of the Medicinal Use of Tobacco 1492-1860}

Nasal polyps, 1821.

Neck, diseases of glands, 1529.

Stiff, 1571, 1746.

Nerves, to comfort, 1711.

Neuralgia, 1845.

Obesity, to prevent, 1614.

Obstructions, in oesophagus, 1614, 1838.

Of stomach, \& hard, 1571, 1597.

Preserved from, 1588.

Pain, 1519, 1711, 1838.

Caused by cold, 1525, 1571, 1579.

Paralysis, 1599.

Paresis of urinary bladder, 1853.

Pectoral griefs, 1633.

Pediculosis, head lice, 1793.

Piles, 1747.

Poison, 1571, 1598.

From arrow, 1571, 1615, 1622.

Antidote to, 1633.

Polyps, inveterate, 1500 .

Pox, 1622.

Procreation, wives to smoke to help, 1690.

Purge, 1602.

Abdomen, 1552.

Breast, 1610.

Head, 1598.

Intestines, 1552, 1571, 1699.

Nasal passages, 1493, 1570, 1598, 1602.

Superfluous fieame and other grosse humours, 1588.

For vomiting, to induce, 1571, 1699.

Rabies (hydrophobia), 1838, 1859.

Respiratory diseases, 1746.

Respiratory stimulant, 1801.

Resuscitation 1774.

Rheumatism, 1595, 1621, 1844, 1854.

Rheums, 1571, 1573, 1582, 1586, 1597, 1598, $1599,1610,1622,1633$.

To distill, 1674.

Defluxion of, 1711.

In head, eyes and stomach, 1595.

To prevent, 1621.

Ringworm, 1560, 1567, 1848.

Scabby rash, 1793.

Scabies, itch, 1824, 1838, 1844.

Scabs, 1567, 1621, 1633.

Scald head, 1848.

Sciatica, 1622.

Scorbutic. 1744.

Scurfy skin, 1793.

Scurvy, 1600, 1602, 1615.

Sedation, to produce, 1810.

Sleep, to induce, 1525, 1595, 1852.

Smallpox, 1622.

Soreness, 1571.

Sores, 1500, 1529, 1560, 1570, 1615, 1621, 1622.

Old, putrid, infected, 1571 .

Old, incurable, 1573.

Of innumerable diseases, 1614.

Pestilential, 1587.
Spasmodic diseases, 1851.

Spirits, to restore, 1570.

Spleen trouble, 1622.

Stomach: ache, 1599, 1746.

Ailments, 1591.

Cold, weak, to heal, 1595, 1602.

Congestion of, 1633.

Corruption, to fetch off, 1595.

Humours, to draw off superfluous from cold and waterish, 1724.

Moisture, to drive from, 1550 .

Obstructions, 1571.

Opilations, 1571, 1595.

Pain, 1571, 1601.

To purge, $1571,1674$.

To void water and fleame from, 1565 .

Strength, to produce, 1570, 1571, 1585, 1591.

Strychnine poisoning, 1859, 1860 .

Suffocation of the mother, 1614.

Surditis (no date given).

Swellings, 1571, 1595, 1622.

Teeth, to clean, 1500, 1744, 1764.

Tetanus, 1610, 1648, 1746, 1815, 1822, 1824, 1826, 1830, 1831, 1836, 1841, 1858.

Thirst, preventive against, 1557, 1570, 1571, $1591,1597$.

Thorax diseases, 1622.

Tic douloureux, 1845.

Toothache, 1571, 1597, 1621, 1622, 1674, 1682, $1685,1711,1724$.

Tooth, decay, 1571.

Defluxion, 1780.

Tuberculosis, 1844

Tumours, 1597, 1851.

Typhus, 1851.

Ulcerous diseases, 1682.

Ulcers, $1500,1560,1567,1571,1573,1582$, $1589,1593,1595,1597,1614,1615,1621$, $1622,1633,1793,1851$.

Urinary calculus (no date).

Vapours, of brain, 1610. Venomous, 1665.

Venereal disease, 1535, 1604.

Vesicular herpes (no date).

Voice, to clear, 1614.

Vomiting, to induce, 1602, 1621.

Warts, 1622.

Waterish diseases, 1602.

Weariness, to take away, 1571, 1622.

Wind, pains from, 1571 .

Wounds, 1519, 1523, 1567, 1570, 1571, 1588, $1589,1595,1597,1602,1614,1621,1622$, 1633, 1659, 1674.

Yaws (eighteenth century, year not stated).

\section{ADDENDA}

To disinfect, 1492.

Fatigue, to prevent, 1492.

To intoxicate, 1493.

Thirst, to relieve, 1499. 


\section{Grace G. Stewart}

APPENDIX No. 4

\section{SAMPLING OF FORMULAE FROM PHARMACOPOEIAS, HERBALS, DISPENSARIES, ETC., 1529-1858}

1529 Sahagún's history of Mexico. For abscesses and sores on the head: Take a little lime mixed with a sufficient quantity of piciete.

Against persistent headaches: Breathe in the odour of the green leaves of piciete.

For a cold or catarrh: Take the plant called piciete, either green leaves or in powder and rub them around the inside of the mouth with the finger.

Diseases of the glands of the neck: Open the place with a small knife and after cutting out the root place on it crushed piciete mixed with the plant called yietl, all hot, with salt, on the same spot.

c.1552 Libellus de medicinalibus Indorum herbis Tlaltelulco, Mexico. For 'Murmur ventris', or rumbling of the abdomen: Use picietl with a number of other ingredients in an enema.

For 'Morbus iterum rediens', i.e. recurrent fever: With juice made by grinding up the herb which has the power of inebriating, which we call piciyetl, salt, black native pepper and pale-coloured pepper his abdomen is to be purged.

1567 L'Agriculture et maison rustique published in Paris. For a sore caused by a cancerous growth: Mash the herb with the pulp and juice together.

For a thumb almost cut off: Treat with a dressing of nicotiane.

For an ulcer on a leg: For ring worm: For King's evil: Treat with a dressing of nicotiane.

For a sore on the face: Treat with a dressing of nicotiane.

For asthma: Water of nicotiane mixed with the liquid of euphrasy.

To cure cancerous sores, all old wounds and cankered ulcers, injuries, ring worms, open scabs, whatever infection is in them: Pound the leaf of the plant in a clean mortar and put pulp and juice on the diseased part.

To eliminate slimy and watery mucous from the mouth: Dry the leaf of the plant, place on a chafing dish to be burned, and take the smoke from this into the mouth through a pipe while keeping the head well covered.

For healing and knitting together all sorts of wounds: Recipe for ointment: Take a pound of fresh leaves of nicotiane, crush them and mix with new wax, rosin and common oil, of which each three ounces, boil all together until the juice of the nicotiane is consumed; then add to it three ounces of Venetian turpentine, pour and strain through a linen cloth and use.

1571 Segunda parte of Monardes published at Seville. To glue together and close fresh wounds and to purify infected sores: Dry the leaves of Picietl and make into powder.

For curing pains of the head, especially those arising from cold, to cure headache coming from cold cause or from a draught: Leaves must be put hot on the aching part, using frequent applications as needed.

To relieve stiff neck because of a cold or because of a draughty place: To relieve pain in the body in whatever part caused by cold: Place hot leaves on the stiffness or pain.

For pains of the chest, especially those which cast forth matter from the mouth and for those caused by asthma and other chronic ailments: A decoction of the herb mixed with sugar into syrup and taken in small quantities expels the matter from the chest and if the smoke is taken into the mouth it casts out the matter from the chests of asthmatics.

For stomach pain caused by cold: Apply the leaves very hot; the leaves be warmed better than in any other way in ashes or very hot embers and even though they be applied with some ashes on them the effect is better and more powerful.

In obstructions of the stomach this plant is a great remedy as it dissolves and consumes them: The herb must be taken green and pounded and with this pulp the hardness must be rubbed a good while and at the time the plant is pounded put in a few drops of vinegar so that it may work better. After rubbing the place put on it a leaf or leaves of the plant hot and leave it until the next day. Then repeat. With this remedy some have dissolved great and hard obstructions and reduced old swellings.

For pains from wind: Apply the leaves in the same manner as explained using applications as hot as possible.

To kill worms: Make a decoction of the plant into a syrup and take in very little quantity. For pains of the joints caused by cold: Put leaves of the plant on hot on the pain.

For swellings and cold abscesses: To dissolve and remove: Wash with hot juice or put on the pulp or the leaves.

To heal grifs of the head especially coming of cold causes: Apply leaves hot to the head.

To eliminate rottenness of the breast: Inhale the smoke at mouth.

For opilations of the stomach: Take green, crush, rub into hardness a good while after adding a few drops of vinegar, continue rubbing.

To reduce swellings: Wash with hot juice.

For toothache: To keep decay from going further: Wash tooth with cloth wet in juice; later a small ball made of a leaf should be applied to the tooth. 


\section{A History of the Medicinal Use of Tobacco 1492-1860}

To heal chilblains: Rub with pounded leaves; put hands and feet in hot water with salt and keep warm.

For wounds from poisoned arrows: Put juice and pulp of the leaves on them.

To purge both upwards and downwards: Fluid of $4 \mathrm{oz}$. of juice.

1579-1581 History of Mexico by Durán. To deaden the flesh so as not to feel pain: Put in much picietl, mix with various insects and make an ointment.

1582 Della fisica by Fiorvanti published in Venice. To cure fevers and ulcers: Prepare decoction of pulverized plant and aqua vitae, distill and add other ingredients; take by mouth and/or wash sores with this.

1587 De herba panacea by Everaerts published at Antwerp. For a very pestilential sore: Apply juice of petum.

1588 A prooued practise by Clowes. For wounds: Use Vnguentú Nicotianu; let the leaves be well stamped and after strained out.

1589 An Antidotarie by Banester published at London. For wounds with gunshot: Balm of Nicotian (attributed to Everaerts). The balm consists of the juice of the plant strained from the stamped leaves with equal parts of olive oil.

For mouth ulcers: Gargarismes (gargles)-prepared from several ingredients of which Nicotian is one.

For healing wounds: For ulcers: And similar ailments: Unguent receipt: The principal ingredient is Nicotian, in the leaf and in juice, which is to be boiled with lard until it has the proper consistency.

1595 Tabaco by Chute published at London. To bring new finger nails: Distilled water of the green leaves to be applied with linen cloths to fingers.

Recipe for ointment (purpose not stated): Take of the choicest and most substantial leaves of the plant, one pound, beat them in a mortar of marble; take one-half pound of sweet hog's grease and this being melted, set it over a fire to seeth until the waterish humour is taken away.

1597 The herball by Gerard published at London. Good against deafness: Drop oil or juice of tabaco into ears.

Curative agent for apostemes, tumours, inveterate ulcers, botches and such like: Make into an unguent or salve as follows: Take of the green leaves $3 \mathrm{lb}$. and one-half, stamp them very small in a stone mortar; of olive oil 1 qt.; set them to boile in brass pan or such like upon a gentle fire, continually stirring it until the herbs seem black and it will not bubble nor boil any more. Then shall you have an excellent green oil which being strained from the feces of dross, put the clear and strained oil to the fire again, adding thereto of wax half $\mathrm{lb}$., of rosin four oz., and of good turpentine $2 \mathrm{oz}$.; melt them altogether and keep it in pots for your use.

$1602 A$ New and Short Defence of Tobacco by Dr. Bellamy published at London. For a purge: Infuse with leaves in white wine or other liquor, some vinegar, cinnamon, nutmegs, mace; licorice and anniseeds may also be added.

1610 The triall of tabacco by Gardiner, published at London. To expel gross and slimy humours from the ventricles of the brain: A specific: Snuff: Rec. Piperis, Zinziberis, ana i, Pyrethri, Foliorum siccorum tabaci ij. Trita naribus inspirentur ante cibum.

Recipe for persons with asthma or consumptive tendency: Foliorum sana sancta Indorum. Styrocis, Sandarachae, Terebenthiae, Mastichis, ana partes equales.

A medicine in the plague effectual if taken warm and perspiration be induced: Pulveris radicis Angelica Hortensis, vel sylvestris, 3 j. Theriacae optima, el, 3 s. Aqua still atitia, sana sancta Indorum, 3. Aceti optimi, 3 Misce.

To discharge the breast from phlegmatic matter: Sirup made of decoction of this herbe with sufficient sugar and so taken in a very small quantity.

To take away all pains of gout: An unguent: Bake the ingredients for $5 \mathrm{hr}$. in a glass vessel: Succi foliorum san. sanct. Indorum 3viij. Axung. porci masculi. Axeng caponis, ana unc. ii Misc.

1622 Tabacologia by Neander published at Leyden. To cure gout: $1 \mathrm{lb}$. tobacco leaves steeped in oil, 12 live frogs, 4 live worms. Adding wine when this combination is well cooked.

As a diuretic in dropsy: Tobacco wine: Leaves of tobacco $1 \mathrm{oz}$., Spanish white wine $1 \mathrm{lb}$., macerate for 7 days, strain through paper. Dose: 6-30 drops, gradually increased to 60 or 80 twice a day.

1659 Everaerts and Neander: Panacea or the Universal Medicine. For fevers and wounds: Recipe: 'I took tobacco with seed and root and stamped them all. The leaves weighed 54 ounces. I hid them in horse dung to ferment thirty days and that they might not corrupt, I put some sale to them and six ounces of aqua vitae. Then I distilled them in Balneo Mariae until all the moisture was drawn from them and that it might keep the better. I added so much oil of brimstone as might make it taste sharp. In all fevers, a spoonful drunk cured them. Wounded men, if they drank it, or anointed their wounds with it were cured to admiration.' 


\section{Grace G. Stewart}

1699 Bate's Dispensary. For a purge or a vomit: Oyl of Tobacco: 'Anoint the pit of the stomach with gr. $v$ or vi and the patient will presently vomit, but if you would move the body downwards, anoint about the navel therewith and the sick will presently fall a purging.'

1774 The Pulmotor of the 18th Century by Warren published at Boston. To restore the apparently drowned: Blow warm breath into the patient's lungs and introduce tobacco smoke not only into the fundament, but into the lungs as well. After tobacco has been lighted in the bowl of a pipe, the bowl should be wrapped in a paper in which several holes are pricked and through these holes force the breath strongly. If a surgeon is present the jugular vein should be opened and about $12 \mathrm{oz}$. of blood taken.

1813 Edinburgh $M$. and S. J., 9: 159-60 by 'Physician'. To treat colic: Administer an enema of the infusion of tobacco in the proportion of half a dram in $12 \mathrm{oz}$. Of water, to be increased gradually if not effective.

1815 Pharmacopoeias of London, Edinburgh and Dublin. Purpose not stated; formula for Vinum nicotianae tabaci: Take leaves of tobacco, $1 \mathrm{oz}$. Spanish white wine $1 \mathrm{lb}$., macerate for 7 days and filter through paper.

1820 Primitive Physic by Wesley published in London. For a nervous headache: (This is of great use even in cancer.) Try a powder of an $\mathbf{0 z}$. of marjoram and half an oz. of assarabacca; mix them and take them as snuff, keeping the ears and throat warm.

To kill head lice: Sprinkle Spanish snuff over the head.

To cure piles: Apply a tobacco leaf steeped in water $24 \mathrm{hr}$.

1848 'Pharmaceutical and Chemical Properties' quoted in The Australasian Journal of Pharmacy, 28: 958-961. Melbourne. Remedy for scald and ring worm: An ointment: $1 \mathrm{oz}$. leaves boiled in lb. lard.

1858 Simon and Clapton in Med. Times \& Gaz., London, 17: 112-113. To treat traumatic tetanus: $\frac{1}{12}$ minim of nicotine hourly, increasing gradually to $\frac{1}{6}$ minim and later to $\frac{1}{4}$ minim hourly.

APPENDIX No. 5

\section{PARTS OF HUMAN BODY WHICH RECEIVED TOBACCO TREATMENT AND FORM IN WHICH TOBACCO WAS USED, 1492-1853}

I. External application to any part of body
A. for pain due to internal or external disorders, and

B. for skin diseases or injuries of any kind

Date first

reported

1602

1589

1822

1582

1836

1571

1587

1492

1595

1529

1851

1571

1595

1560

1840

1560

1571

1821 ashes, tobacco, pipe

balm

cataplasm

decoction

fumes

juice, hot

juice, cold

leaves, green or dry

bruised

crushed

dipped into hot water

hot

in hot embers

mashed

moistened

pounded

roasted

steeped in water

$\begin{array}{ll}\text { Date first } \\ \text { reported } \\ 1824 & \text { lotion } \\ 1800 & \text { mush } \\ 1622 & \text { oil } \\ 1560 & \text { ointment } \\ 1579 & \text { plaster, tobacco } \\ 1828 & \text { plaster, snuff } \\ 1560 & \text { poultice, tobacco dressing } \\ \text { After } & \\ 1607 & \text { poultice, chewed-tobacco } \\ 1571 & \text { pulp } \\ 1622 & \text { salve, snuff } \\ 1524 & \text { smoke, cigar } \\ 1571 & \text { snuff } \\ 1851 & \text { tobacco spittle } \\ 1588 & \text { unguent }\end{array}$

II. Internal use

A. Introduced into all openings of the head to treat diseases of:
1. Ears
1597
2. Eyes
1764
oil or juice dropped into
smoke blown into
1599 juice to cleanse 


\begin{tabular}{|c|c|c|}
\hline 3. Mouth & $\begin{array}{l}1525 \\
1529 \\
1571 \\
1571 \\
1574 \\
1589 \\
1614 \\
1685\end{array}$ & $\begin{array}{l}\text { snuff held in mouth } \\
\text { green leaves held in mouth } \\
\text { small ball chewed } \\
\text { round ball of leaves held in mouth } \\
\text { green chewed } \\
\text { gargle-a compound } \\
\text { spittle, expectorate to purge } \\
\text { pills held in mouth }\end{array}$ \\
\hline 1. Nose & $\begin{array}{c}1493 \\
1820 \\
?\end{array}$ & $\begin{array}{l}\text { smoke of snuff inhaled } \\
\text { snuff blown up nose of patient by physician } \\
\text { snuff pellets inserted in nostrils }\end{array}$ \\
\hline
\end{tabular}

B. Introduced into mouth to reach other organs

\begin{tabular}{|c|c|c|c|}
\hline & Lungs & $\begin{array}{l}\text { Reported } \\
1492 \\
1774\end{array}$ & $\begin{array}{l}\text { Cigar smoke } \\
\text { Smoke introduced directly by physician }\end{array}$ \\
\hline 2. & Stomach & $\begin{array}{l}1838 \\
1851 \\
1571 \\
1622 \\
1557 \\
1571 \\
1571 \\
1852 \\
1800 \\
1851 \\
1614 \\
1614 \\
1821 \\
1839 \\
1591 \\
1571 \\
1573 \\
1564 \\
1570 \\
1591 \\
1535 \\
1571 \\
1622 \\
1850 \\
1560 \\
1852 \\
1622\end{array}$ & $\begin{array}{l}\text { Aetherial tincture } \\
\text { Ashes, pipe } \\
\text { Decoction } \\
\text { Gruel } \\
\text { Juice of leaf sucked } \\
\text { Juice, boiled and uncooked } \\
\text { Leaves, dry, smoke of, sucked } \\
\text { Leaves soaked in goat's milk } \\
\text { Mush } \\
\text { Nicotine } \\
\text { Oil } \\
\text { Pills } \\
\text { Powder } \\
\text { Smoke, deglutition of } \\
\text { Smoke, cigar, inhaled } \\
\text { Smoke inhaled and exhaled } \\
\text { Smoke, pipe, inhaled } \\
\text { Smoke sucked through cane and swallowed } \\
\text { Smoke sucked through tube of palm leaves or straw } \\
\text { Smoke drawn through corn husk or reed and swallowed } \\
\text { Snuff smoked in pipe and swallowed } \\
\text { Syrup } \\
\text { Tea } \\
\text { In water } \\
\text { Water, distilled from } \\
\text { Water impregnated with smoke } \\
\text { Wine }\end{array}$ \\
\hline J. & Teeth & $\begin{array}{l}1571 \\
1571 \\
1764\end{array}$ & $\begin{array}{l}\text { Juice } \\
\text { Leaf } \\
\text { Ashes, }\end{array}$ \\
\hline
\end{tabular}

C. Introduced into nostrils to reach lungs

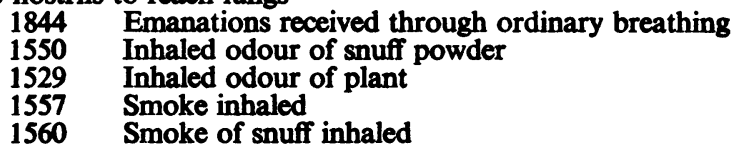

D. Introduced into intestinal canal

$\begin{array}{ll}1622 & \text { Clyster, tobacco } \\ 1671 & \text { Clyster, smoke } \\ 1762 & \text { Enema infusion } \\ 1552 & \text { Juice of ground tobacco by injection } \\ 1851 & \text { Wet leaf introduced into extremity of bowel }\end{array}$

E. Introduced into urinary bladder, male patient

1853 Solution of nicotine introduced by catheter

F. Introduced into vagina

1830 Tobacco injection 


\section{EARLY OBSERVATIONS ON THE NARCOTIC EFFECTS OF TOBACCO 1493-1665}

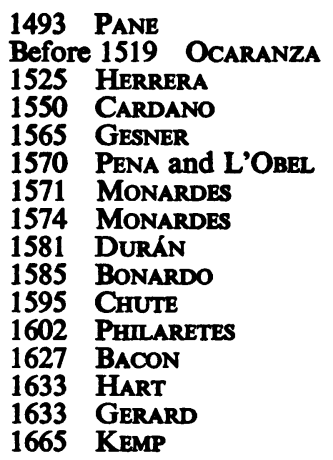

Stupefies

Narcotizes

Causes men to fall asleep and feel no pain

It inebriates

Produces dizziness

Lulls brains

Relieves pain; takes weariness away

Causes people to be out of their mind

Deadens fiesh so as to feel no pain

Causes men to fall into a pleasant sleep

Produces sound sleep

Stupefies

Has opiate virtue

Makes dull and sleepy

Makes dull and sleepy

Will make one rest that wants sleep

APPENDIX No. 7

HOW THE PLANT WAS HANDLED, PHYSICALLY (between 1492 and 1840)

\section{Date first}

reported

I. How the plant was handled Nicotine extracted ... .. 1828

II. How the parts of the plant were handled

Leaves, dry

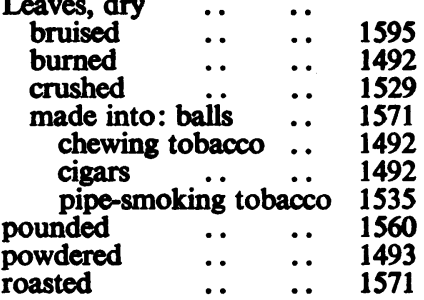

2. Leaves, green

beaten into mush .. 1800

boiled and strained ... 1597

$\begin{array}{llll}\text { chewed } & . & . & 1499\end{array}$

crushed $\quad . .10 .1529$

distilled to obtain juice 1560

which was then heated 1571

and/or boiled .. 1597
Date first reported

Leaves, green oil extracted .. $\quad$.. 1597 ground to obtain juice 1552 placed in hot embers 1595 pounded .. .. 1571

3. Leaves, not stated whether dry or green dipped in hot water 1851 $\begin{array}{llll}\text { heated } & . & . & 1571\end{array}$ moistened $\quad . \quad \ldots \quad . .1840$ soaked in goat's milk 1852 stamped $\quad . . \quad$.. $\quad 1588$ steeped in water $\quad . . \quad 1821$

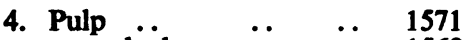
$\begin{array}{llll}\text { mashed } & . . & \ldots & 1560\end{array}$

5. Roots (how, not stated) 1614

6. Seeds (how, not stated) 1610

7. Stalk (how, not stated) 1614

APPENDIX No. 8

TOBACCO ELEMENTS, COMPOUNDS, BY-PRODUCTS PRESCRIBED AS MEDICINE, 1492-1851

Date
first
reported
1844
1492
1492

Elements of
the simple
remedy
emanations
leaves $\quad$.
odour..

Compounds using tobacco

Medicinal By-Products with other ingredients

.. $\quad . .1838$ aetherial tincture $\quad \ldots 1614$ ashes, tobacco

.. $\quad . .1589$ balm $1 . . \quad$.. $\quad$.. 1602

. 1824

cataplasm $\quad \ldots \quad \ldots 1836$

ashes, pipe 
A History of the Medicinal Use of Tobacco 1492-1860

\begin{tabular}{|c|c|c|c|c|c|c|c|c|c|c|}
\hline \multirow[b]{2}{*}{$\begin{array}{c}\text { Date } \\
\text { first } \\
\text { reported } \\
1614 \\
1610 \\
1493 \\
1614 \\
\end{array}$} & \multirow{2}{*}{\multicolumn{2}{|c|}{$\begin{array}{c}\begin{array}{c}\text { Elements of } \\
\text { the simple } \\
\text { remedy } \\
\text { root }\end{array} \\
\begin{array}{l}\text { seeds } \\
\text { snuff }\end{array} \\
\text { stalk }\end{array}$}} & \multirow[b]{2}{*}{$\begin{array}{l}\ddot{ } \\
\ddot{*} \\
\ddot{ }\end{array}$} & \multicolumn{4}{|c|}{$\begin{array}{l}\text { Compounds using tobacco } \\
\text { with other ingredients }\end{array}$} & \multicolumn{3}{|c|}{ Medicinal By-Products } \\
\hline & & & & $\begin{array}{l}\ddot{ } \\
\ddot{ } \\
\ddot{ }\end{array}$ & $\begin{array}{l}1622 \\
1571 \\
1589 \\
1622 \\
1762 \\
1560 \\
1622 \\
1828 \\
1614 \\
1822 \\
1571 \\
1622 \\
1821 \\
1571 \\
1622 \\
1588 \\
1589 \\
1622\end{array}$ & $\begin{array}{l}\text { clyster ... } \\
\text { decoction } \\
\text { gargle } \\
\text { gruel } \\
\text { infusion } \\
\text { lotion } \\
\text { ointment } \\
\text { pellets, snuff } \\
\text { pills } \\
\text { plaster, snuff } \\
\text { plaster } \\
\text { poultice } \\
\text { powders } \\
\text { salve, snuff } \\
\text { snuff mixtures } \\
\text { syrup } \\
\text { tea } \\
\text { unguent } \\
\text { waters } \\
\text { wine }\end{array}$ & $\ddot{x}$ & $\ddot{m}$ & $\begin{array}{l}1492 \\
1851\end{array}$ & $\begin{array}{l}\text { smoke } \\
\text { spittle }\end{array}$ \\
\hline
\end{tabular}

INSTRUMENTS USED TO ADMINISTER TOBACCO MEDICATION, 1492-1830

\section{Date first}

reported

1518

1493

1854

1661

1529

1591

1535 cane, small

cane, one foot long

catheter, male patient

clyster, smoke

finger

husks, corn, to wrap cigar

pipe, smoking
Date first

reported

1591 reed

1570 straws

1552 syringe, rectal

1830 syringe, vaginal

1493 tube, bifurcated (taboca)

1570 tube, palm leaf

APPENDIX No. 9

\section{RECORD OF HARMFUL EFFECTS OF THERAPEUTIC TOBACCO REPORTED AND OF THE WARNINGS ISSUED AS TO THE USE OF MEDICINAL TOBACCO, 1492-1851}

Date

1492 ColumBus Harmful effect: decayed teeth.

1550 CARDANO By odour alone, renders people distraught. If drunk, causes madness.

1557 THEVET It causes weakness, even fainting.

1565 GesNer Causes dizziness.

1573 HARRISON The smoke or vapour thereof is not so profitable to be receaved inwardly.

1574 DoDoEns It should only be prescribed for warm and robust constitutions. The use of this kind of henbane or of its leaves is not safe for weak and old people. It is better to mix the leaves of this with others in order to temper its coldness.

1586 CAmerartus Advised against its indiscriminate use in all cases where medical treatment is required.

1588 CLowes I found not that effect in it that I looked for.

1591 CARDENAS Should not be taken in curing ailments accompanied by heat and inflammation or where there is an effusion of blood from any part of the body. Warned against taking too much smoke after eating for fear of intoxication or some harm to the system. Severe warning that smoking should be permitted only to those trying to cure some unhealthy condition.

1595 CHUTE Warns against smoking unless persons find themselves cold in their stomach, rheumatic or having the headache, etc.

1597 GERARD It might relieve for a time but would never perform any cure. Taken after meals it doth much hurt, for it infecteth the brain and liver.

1600 VAughaN Tobacco should be avoided by lean, choleric and melancholy persons and by young people, women with child, husbands who desire to have children, and especially all such under 50 years of age whose brains were hot and dry. Tobacco was as violent as quicksilver, brought fear and dullness to the understanding, will and memory. 


\section{Grace G. Stewart}

1602 Philaretes No one remedy could be applied to all maladies. Tobacco purged its users too violently, dried up the sperm of a man so that if used overlong the propagation and continuation of mankind must needs be abridged; also withered and dried up natural moisture of the body; tobacco in substance and nature was deleterious and venemous; had a stupefying effect, not unlike opium; increased melancholy greatly and wasted the liquid part of the blood.

1604 KING JAMES I Autopsies performed on some notorious smokers revealed that their inward parts were soiled and infected with an oily kind of soot. Tobacco harmful to the brain, dangerous to the lungs.

1610 GARDINER Some poison existed in tobacco; tobacco relieved, rather than cured. Advised great discretion in use of tobacco, recommending that the nature of every patient be well considered and the proper cure fitted to him.

1615 SYLVESTER No plant except hemp so pernicious to man's life as tobacco. Tobacco caused moist brain, dried the blood, dulled the intellect, marred the memory, made men heedless and quarrelsome, and dried up the seed of generation.

1616 DEACON Tobacco dangerous to bodily health.

1617 BRATHWATr Jeered at the notion of tobacco as the only sovereign experimental cure; diminished men's valour.

1619 Corta Critical: Is not now this high placed remedy discovered to be a monster of many diseases?

1619 English Government Proclamation: Tobacco tended to a general corruption of men's bodies and manners.

1621 VENNER Deplored immoderate use on ground that smoking increased insensibility.

1622 NeANDER A plant of God's own making, but the devil likewise involved; excesses ruined both mind and body.

1625 BRADWELL No efficacy against the pestilence.

1633 Made its users dull and sleepy; excessive use encouraged drinking, hastened old age, no friend to generation.

1633 HART Tobacco a poison as strong as the strongest purging and having violent purging quality itself. By its narcotic quality stupefied the senses. Moderate exercise and good diet better than tobacco. Advised melancholy persons, choleric, hot brained persons, women with child and those with acute diseases to abstain; warned that excessive usage caused many dangerous diseases.

1634 LeIVA Denied the values of a considerable part of nicotian therapeutics.

1639-51 Primrose Advocated caution in using tobacco therapeutically.

1670 KERCKRING Dissections of corpses of smokers; have odour of poison.

1674 JosselYN Immoderately taken tobacco dryeth the body, enflameth the blood, hurteth the brain, weakens the eyes and sinews.

1724 CHEYNE Users should carefully avoid swallowing the smoke or the juice.

1750 HIIL Snuff dangerous to the senses; might even induce death.

1802 Wrich Did not consider injection of the smoke of tobacco or even clysters of that narcotic plant in all instances safe.

1810 Pharmacopobia Gives formula for Vinum nicotianae tabaci but adds the caution that it is far from safe.

1848 Pharmacoporin Gives prescription for tobacco enema to be used for strangulated herniaa remedy too dangerous to use except in extreme cases.

1851 CoLES Tobacco is the greatest enemy of physical life. Doubtless, with other kindred poisons, was intended for medicinal purposes. This article has often been prescribed where the remedy was infinitely worse than the disease .... it never cures the disease .... it is never taken like other medicines, and then laid aside. When prescribed in justifiable cases, tobacco needs to be used with great caution, knowledge, and skill, or it becomes a very unsafe, and even fatal medicine. Its use by the mouth is, in about all cases, uncalled for, inexpedient, and even morally wrong. It is fit for the fundament, but not for the mouth. When used as an injection, great caution is essential to the safety of the patient. Sometimes death has been occasioned by this kind of use in unskilful hands. By being injudiciously applied to a spot where the scarf-skin is destroyed, fearful results have followed.

\section{APPENDIX No. 10}

\section{THE PANACEA DOCTRINE}

1500 GoEs Fumo cures many ailments in which the skill of doctors is fruitless; it cures many other ailments.

1524 VERRAZANO Smoke heals any ailment.

1571 MONARDES Sana sancta cures a list of 48 diseases and much else.

1572 Tobacco being hailed as a panacea.

1573 HARRIson The herb is a sovereign healer.

1579 DURÁN The herb is holy. 


\section{A History of the Medicinal Use of Tobacco 1492-1860}

1582 FIORVANTI The herb is of divine origin.

1586 D'Aléchamps A panacea for all sorts of ailments.

1588 HARIOT The Indians of Virginia who use vppowoc are notably preserved in health and know not many grievous diseases wherewithal people in England are oftentimes afflicted.

1591 CARDENAS To seek to tell the virtues of this holy herb, the ailments which can be cured by it and have been, the evils from which it has saved thousands, would be to go on to infinity.

1595 CHUTE Anything that harms a man inwardly from his girdle upward might be removed by a moderate use of the herb.

1602 BELLAMY The plant is commendable for men of any age, constitution or condition.

1614 Barclay Eulogized tobacco; said that every part was medicine-root, stalk, leaves, seeds, smoking ashes. Cured almost all diseases.

1621 BURTON A sovereign remedy; a virtuous herb.

1622 NEANDER A plant of God's own making. Good for every condition.

1633 GERARD Tobacco would cure all the best known diseases; it was a jewel; if he should set down at large all the ailments that tobacco would cure, it would require a big volume.

1643 LifbaulT Medicinal uses of tobacco for almost every human ailment.

1648 MAGNEN Discovered new medicinal uses for tabaco.

1659 EVERAERTS and NEANDER English trans. as Panacea; or the universal medicine.

1665 KEMP All ages, sexes, all constitutions, young and old, men and women, the sanguine, the cholerick, the melancholy, the phlegmatic take tobacco without any manifest inconvenience.

1668 PRADE The use of snuff improved the whole body.

1674 JosselyN Listed many conditions that American colonists treated with tobacco.

1749 Imperial snuff sold for all diseases in head and for all disorders of body and mind.

APPENDIX No. 11

BOOKS PUBLISHED DURING THE LONDON TOBACCO CONTROVERSY, 1602-1665,

\begin{tabular}{|c|c|}
\hline $\begin{array}{l}\text { Year } \\
1602 \\
1602 \\
1602 \\
1602 \\
1604 \\
1606 \\
1606\end{array}$ & $\begin{array}{l}\text { Author } \\
\text { PHILARETES (Pseud.) } \\
\text { MARBECKE, ROBER } \\
\text { BEAUMONT, SIR JoHN } \\
\text { JAMES I } \\
\text { CHAPMAN, GEORGE } \\
\text { E. D. }\end{array}$ \\
\hline $\begin{array}{l}1606 \\
1610\end{array}$ & $\begin{array}{l}\text { ESTIENNE, CHARLES and } \\
\text { LIEBAULT, JEAN } \\
\text { GARDINER, EDMUND }\end{array}$ \\
\hline $\begin{array}{l}1611 \\
1612 \\
1614 \\
1615 \\
1616 \\
1617 \\
1617 \\
1617 \\
1619\end{array}$ & $\begin{array}{l}\text { L'OBEL, MATTHIAS DE } \\
\text { VAUGHAN, WILLIAM } \\
\text { BARCLAY, WILLIAM } \\
\text { RICH, BARNABY } \\
\text { r } \\
\text { SYLVESTER, JOSHUA } \\
\text { DEACON, JOHN } \\
\text { BRATHWWAT, RICHARD } \\
\text { COTTA, JOHN }\end{array}$ \\
\hline $\begin{array}{l}1621 \\
1621\end{array}$ & $\begin{array}{l}\text { BURTON, ROBERT } \\
\text { VENNER, TOBIAS }\end{array}$ \\
\hline $\begin{array}{l}1624 \\
1627 \\
1633 \\
1633 \\
1638 \\
1651 \\
1651\end{array}$ & $\begin{array}{l}\text { GARDINER, EDMUND } \\
\text { BACON, FRANCIS } \\
\text { BRADWELL, STEVEN } \\
\text { HART, JAMES } \\
\text { BACON, FRANCIS } \\
\text { THORIUS, RAPHAEL } \\
\text { PRIMROSE, JAMES }\end{array}$ \\
\hline $\begin{array}{l}165 \\
165\end{array}$ & $\begin{array}{l}\text { RUMSEY, WALTER } \\
\text { EVERAERTS, GILLES and } \\
\text { NEANDER, JOHANN } \\
\text { KEMP, WILLIAM }\end{array}$ \\
\hline
\end{tabular}

Author's Profession

Unknown

Physician

Physician

Poet

King of England

Dramatist

Member of the medical fraternity

\section{Physicians}

Practitioner in Physicke

Physician

Writer

Physician

Writer

Poet

Writer

Poet

Doctor of Physicke

Unknown
Physician

Philosopher

Unknown

Doctor in physic

Philosopher

Poet

Unknown

Judge

Physicians

Mr. of Arts

\section{Book Title}

Work for chimny-sweepers.

$A$ defence of Tabacco.

$A$ new and short Defense of Tobacco.

Metamorphoses of Tabacco.

A counterblaste to tobacco.

Monsieur d'Olive.

The copy of a letter.

The countrey Farme.

The triall of tabacco.

Perfuming of Tabacco.

Directions for Health.

Nepenthes the Vertues of Tabacco.

The honestie of this age.

Tobacco battered.

Tobacco tortured.

The smoaking age.

$A$ short discovery of several sorts of ignorant and inconsidered practisers.

The anatomy of melancholy.

$A$ briefe and accurate treatise, concerning . . . tobacco.

Physicall and approved medicines.

Sylva Sylvarum.

Helps for suddain accidents.

The diet of the diseased.

The historie of life and death.

Hymnus tabaci.

Title unknown: Advocated caution in using tobacco therapeutically.

Organon Salutis.

Panacea; or the universal medicine. God's own making, Devil involved.

$A$ brief treatise of the nature, causes, signes, preservation from, and cure of the pestilence. 


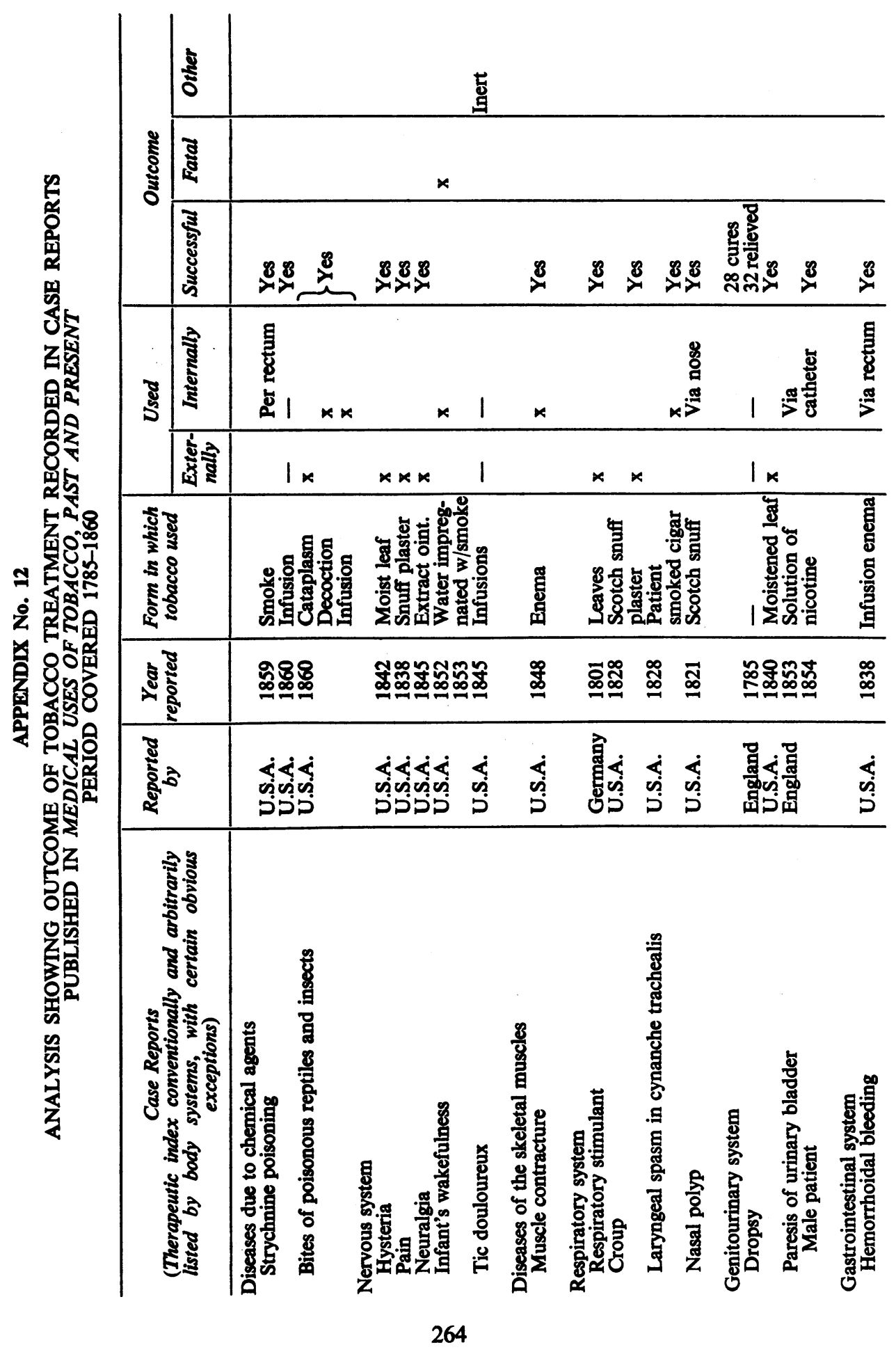




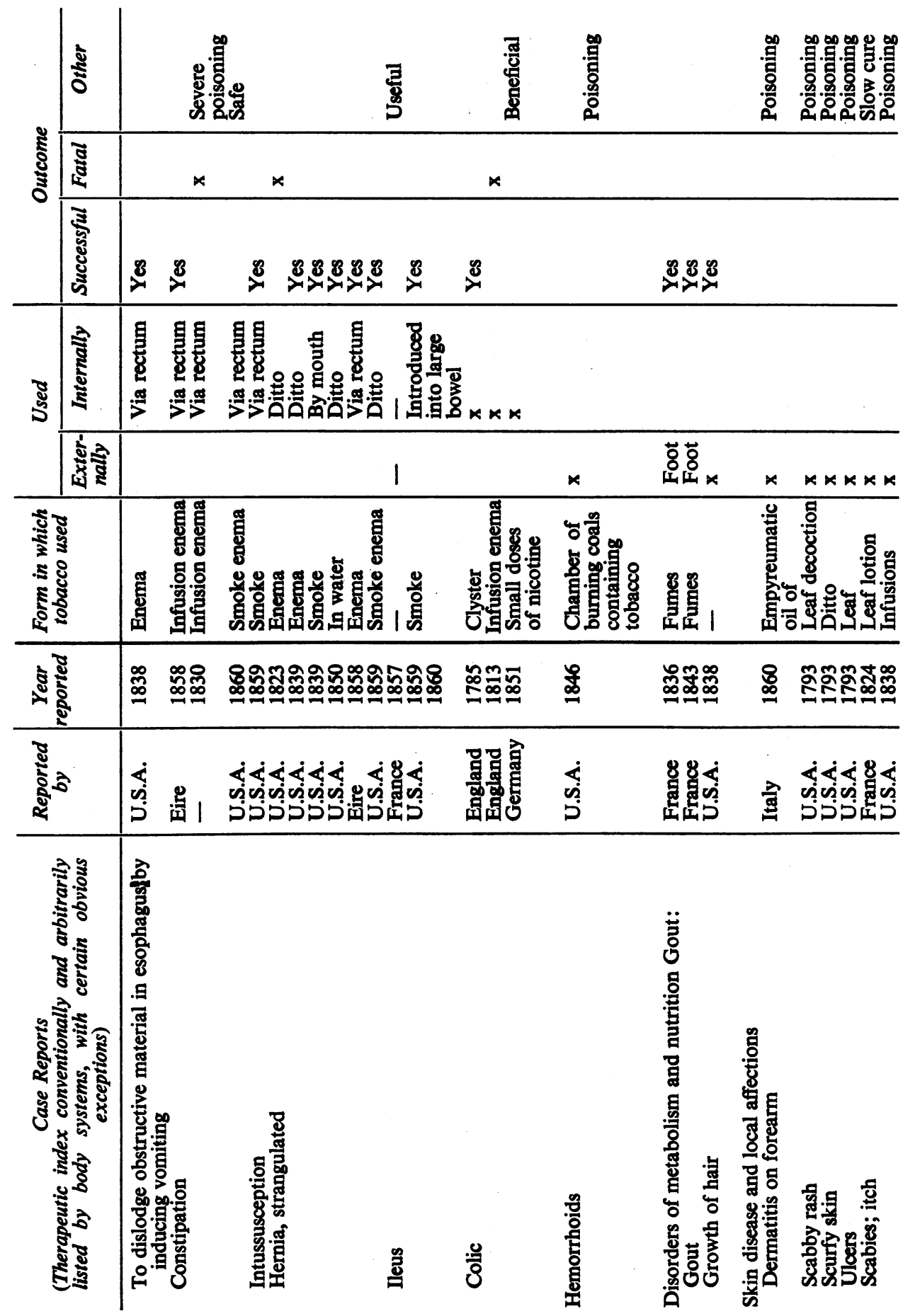




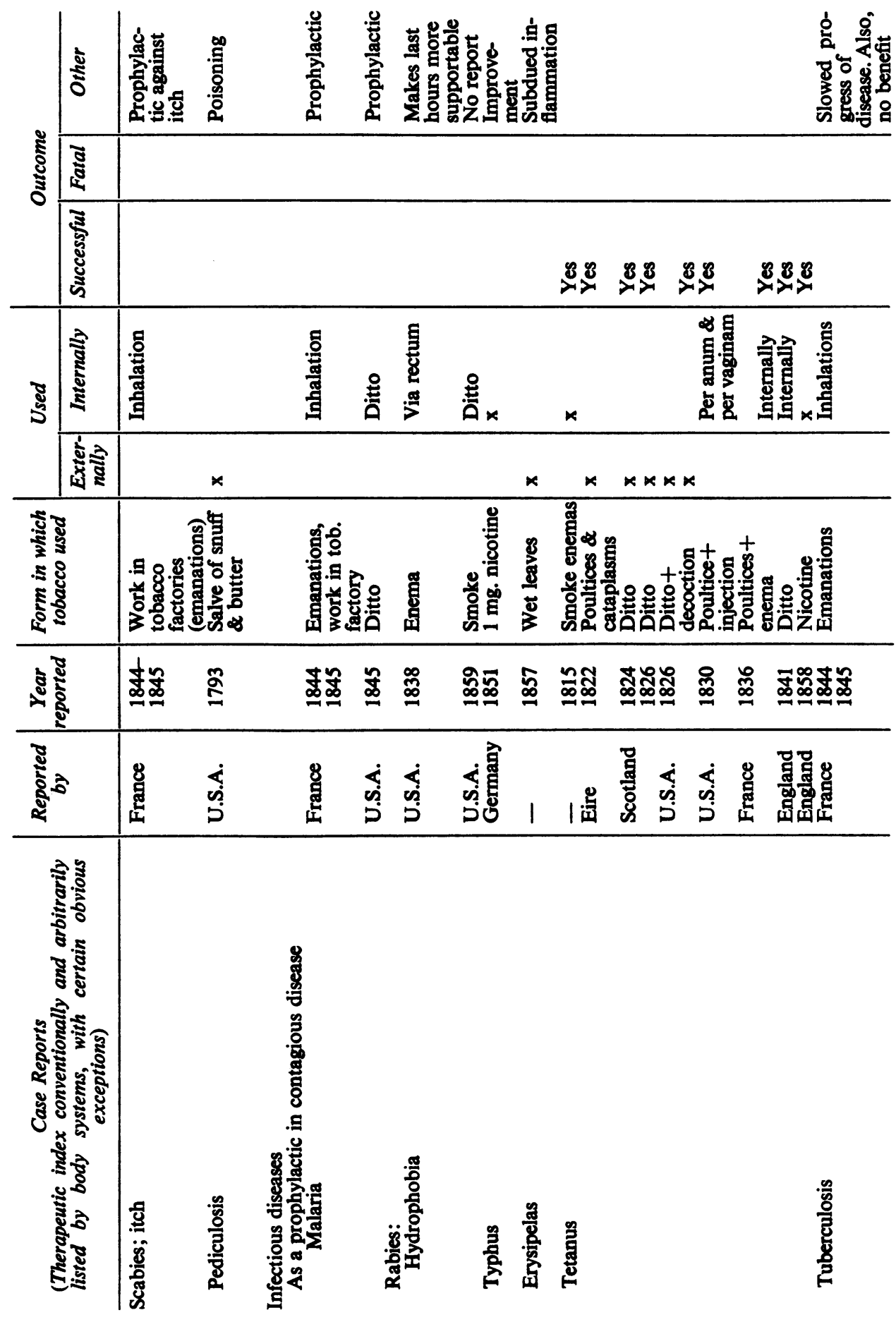




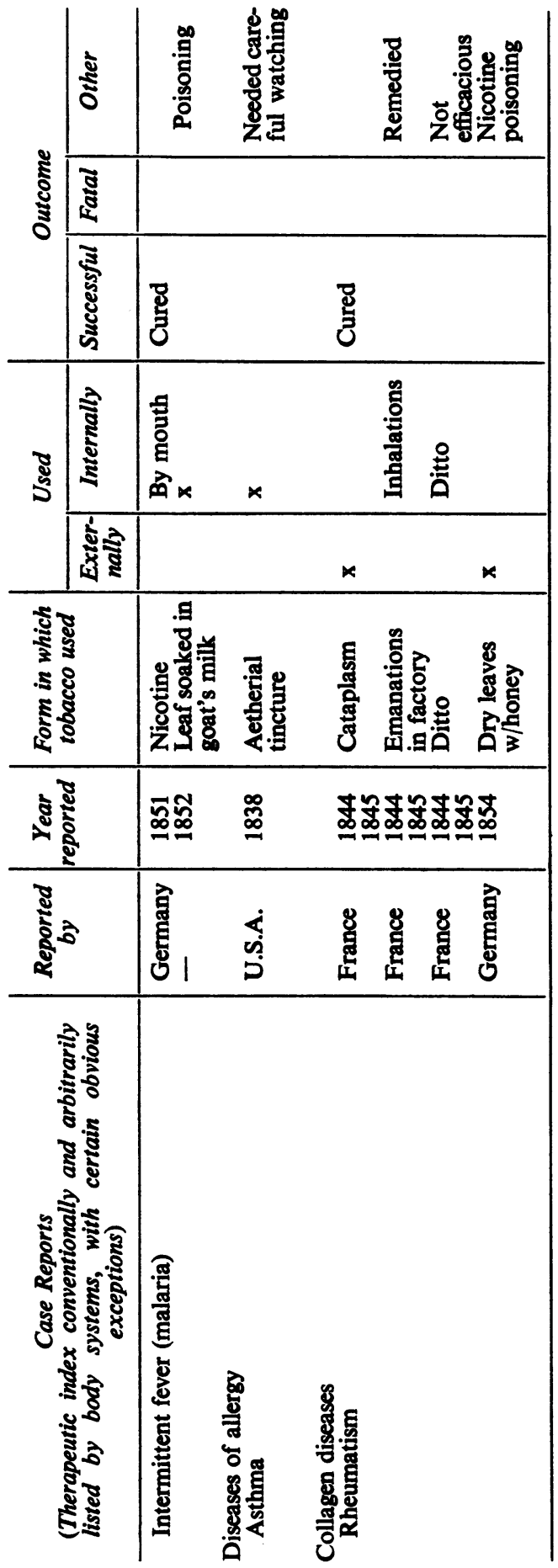




\section{Grace G. Stewart}

\section{LIST OF WORKS CONSULTED}

Brooks, Jerome EdMUND, Descriptive Notes Adapted from Books, Manuscripts and Drawings Relating to Tobacco from the Collection of George Arents, Jr., Washington, 1938.

Brooks, Jerome Edmund, The Mighty Leaf Tobacco through the Centuries, Boston, 1952.

Brown, William, Pharmacopoeia Simpliciorum and Efficaciorum, Philadelphia, 1778.

CARson, Gerald, Old Country Store.

Chamber's Encyclopoedia, 'Tobacco, Physiological Effects', vol. 13, New York, 1950.

Colmman, Edrth, 'From Physician to Good Fellow', Austral. J. Pharm., 1947, 28, 958-61.

Colrs, LARKIN B., M.D., Beauties and Deformities of Tobacco-Using, Boston, 1851.

The Consumers Union Report on Smoking and the Public Interest, ed. Ruth and Edward Brecher, Arthur Herzog, Walter Goodman, Gerald Walker and the editors of Consumer Reports, Mount Vernon, N.Y., 1963.

Dickson, Sarah Augusta, Panacea or Precious Bane, New York, 1954.

FAIRHOLT, F. W., Tobacco: Its History and Associations, London, 1859.

Gentleman's Progress, The Itinerarium of Dr. Alexander Hamilton 1744, ed. Carl Bridenbaugh, Chapel Hill, N.C., 1948.

A Guide to Pipe Smoking and its History, ed. Jerry Nagler, New York, no date given.

Gordon, BenJamin LeE, M.D., The Romance of Medicine, Philadelphia, 1949.

Griffenhagen, George B., and James HaRveY Young, Old English Patent Medicines in America, Washington, 1959.

Hammond's Atlas of American History, C. S. Hammond \& Co., Maplewood, N.J., 1963.

HILL, WesLeY, John Wesley among the Physicians, London, 1958.

Hindle, Brooke, Pursuit of Science in Revolutionary America, 1735-1789, 1956.

Krout, JoHn A., United States to 1865, New York, 1963.

LAURENT, ÉmIL, Le Nicotisme, Société Editions Scientifiques, 1893, 739-83.

Macht, Davm I., 'Toxicologic note on tobacco,' J. Amer. Med. Assoc., 88, Sept. 10, 1927.

MAssengill, Samuel Evans, A Sketch of Medicine and Pharmacy, Bristol, Tenn., 1943.

Mullett, Charles F., 'Tobacco as a drug in earlier English medicine', Ann. Med. Hist., 1940, 2 (2), 1940, 110-123.

Nicholls, Albert G. 'Herba Panacea', Canad. Med. Assoc. J., 46 (3), Mar. 1942, 277-281.

PaCKard, Francts RandolPh, History of Medicine in the United States, VI, New York, 1931.

Partington, J. R., History of Chemistry, 4 vols., London, Macmillan, 1961-64.

Pickard, Madge E., and Buley, R. Carlyle, Midwest Pioneer, His Ills, Cures, and Doctors, Crawfordsville, Ind., 1945.

Ramsey, Euizabeth, 'The History of Tobacco Production in the Connecticut Valley', Smith College Studies in History, 15, April-July 1930, 95-206.

RIEgel, Robert E., America Moves West, New York, 1957.

SChOEPf, JohaNn DAVID. Materia Medica Americana potissimum regni vegetabilis, erlange sumtibus 10, Bulletin No. 6, Lloyd Library of Botany, Pharmacy and Materia Medica, Cincinnati, 1903.

SilVette, H., LARson, P. S., and HaAg, H. B., 'Medical uses of tobacco past and present', Virginia med. Monthly, 1958, 85, 472-484.

Smoking: Facts You Should Know, American Medical Association, Chicago, 1964.

Telford, JoHn, The Life of John Wesley, New York, year not given.

Thomson, John, The Pharmacopoeias of the London, Edinburgh, and Dublin Colleges, Edinburgh, 1815.

Tobacco. Its History Illustrated by the Books, Manuscripts and Engravings in the Library of George Arents, Jr., ed. Jerome E. Brooks, New York, 1937-1943.

Warren, J. Collins, 'The pulmotor of the eighteenth century', Ann. Med. Hist., 1918, 2 (1), 14-20.

Wesley, John, Primitive Physic, or an Easy and Natural Method of Curing Most Diseases, London, 1820.

Young, James Harvey, The Toadstool Millionaires, A Social History of Patent Medicines in America before Federal Regulation, Princeton, N.J., 1961. 